Universidade de Brasília

Faculdade de Economia, Administração, Contabilidade e Ciências da Informação e Documentação

MARIA TEODORA FARIAS TRALDI

\title{
COMPROMETIMENTO, BEM-ESTAR E SATISFAÇÃO NO TRABALHO: a experiência dos professores de Administração da Universidade de Brasília
}


Universidade de Brasília

Faculdade de Economia, Administração, Contabilidade e Ciências da Informação e Documentação

\title{
COMPROMETIMENTO, BEM-ESTAR E SATISFAÇÃO NO TRABALHO: a experiência dos professores de Administração da Universidade de Brasília
}

Monografia apresentada ao Departamento de Administração como requisito parcial à obtenção do título de Bacharel em Administração.

Professora Orientadora: Drª . Gisela Demo Fiuza

\author{
Brasília - DF \\ Dezembro / 2009
}


Traldi, Maria Teodora Farias.

Comprometimento, bem-estar e satisfação no trabalho: a experiência dos professores de Administração da Universidade de Brasília / Maria Teodora Farias Traldi. - Brasília, 2009.

$89 \mathrm{f}$. : il.

Monografia (bacharelado) - Universidade de Brasília, Departamento de Administração, 2010.

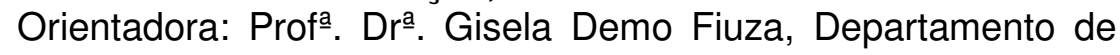
Administração.

1. Comprometimento organizacional. 2. Bem-estar no trabalho. 3. Satisfação no trabalho. I. Título: Subtítulo. 


\title{
Universidade de Brasília
}

Faculdade de Economia, Administração, Contabilidade e Ciências da Informação e Documentação

\section{COMPROMETIMENTO, BEM-ESTAR E SATISFAÇÃO NO}

\section{TRABALHO: a experiência dos professores de Administração da} Universidade de Brasília

A Comissão Examinadora, abaixo identificada, aprova o Trabalho de Conclusão do Curso de Administração da Universidade de Brasília da aluna

\section{Maria Teodora Farias Traldi}

\author{
Drâ. Gisela Demo Fiuza \\ Professora-Orientadora


Dedico à minha mãe que sempre acreditou na importância do equilíbrio entre a capacidade intelectual, o autoconhecimento e a inteligência emocional. Você inspira o meu sucesso e superação. Muito obrigada! 
À professora Drâ. Gisela Demo, minha disputada orientadora, que faz da experiência de aprendizagem algo realmente único e agradável, desenvolvendo o que há de melhor em mim.

Ao querido professor Domingos Sávio Spezia que com paciência, carinho, bom humor e confiança vem me brindando com uma rica oportunidade de crescimento profissional e pessoal.

À professora Késia Rozzett que com sua competência e boa vontade respondeu às minhas mais diversas dúvidas. Sua paciência e atenção tornaram as normas da ABNT mais amigáveis.

Ao professor Pedro Meneses que compartilhou seu valioso conhecimento.

Meu especial agradecimento aos professores que gentilmente participaram da pesquisa, viabilizando a realização deste trabalho.

Aos colegas Marluci Ribeiro de Oliveira, Luiz Carlos Alves e Cláudia Fernanda de Godoy, os quais, pelo empenho, dedicação e vontade de aprender, sempre me despertaram admiração.

Aos servidores do Departamento de Administração da UnB, que me auxiliaram a localizar vários professores para a aplicação dos questionários, especialmente Wallace Bastos, Vanderléa Cassiano e Leonardo Ferreira. Vocês me ajudaram bastante! 


\section{RESUMO}

O objetivo precípuo desta pesquisa foi investigar a relação entre a variável "comprometimento organizacional" e as variáveis "bem-estar no trabalho" e "satisfação no trabalho". Acredita-se que quanto maior o nível de comprometimento organizacional, maiores sejam os níveis de bem-estar no trabalho e satisfação no trabalho. Essa pesquisa consiste em um estudo explicativo, quantitativo e transversal e foi realizada junto aos professores que lecionam ao menos uma disciplina de Administração na Universidade de Brasília. Os resultados obtidos por regressões múltiplas mostraram que o comprometimento organizacional afetivo contribuiu para a explicação e apresentou relações positivas com as dimensões "afetos positivos" e "realização" do bem-estar no trabalho, assim como com a "satisfação com os colegas", com a "satisfação com a natureza do trabalho", com a "satisfação com a chefia" e com a "satisfação com as promoções". O comprometimento organizacional afetivo apresentou relação negativa com a dimensão "afetos negativos" do bem-estar no trabalho. O comprometimento organizacional na base calculativa explicou a "satisfação com o salário", a "satisfação com a chefia" e a "satisfação com as promoções". O comprometimento organizacional na base normativa explicou a "satisfação com o salário". Este trabalho pode contribuir tanto para a produção acadêmica da área do comportamento organizacional como para a gestão dos professores pesquisados.

1.Comprometimento 2.Bem-estar no trabalho 3.Satisfação no trabalho
organizacional




\section{LISTA DE GRÁFICOS}

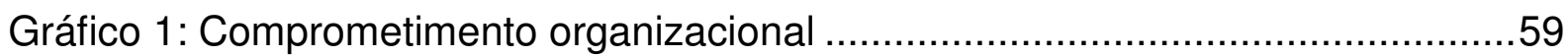

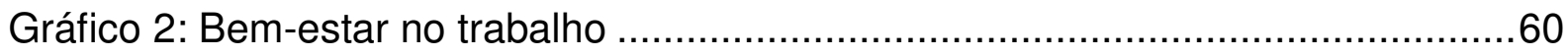

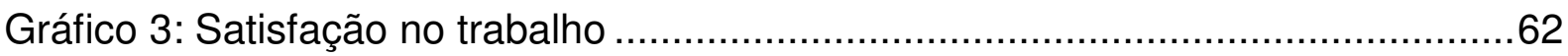

\section{LISTA DE FIGURAS}

Figura 1: Submodelos de pesquisa ....................................................... 47

Figura 2: Os melhores preditores de cada fator das variáveis dependentes............72

\section{LISTA DE QUADROS}

Quadro 1: Variáveis da pesquisa 


\section{LISTA DE TABELAS}

Tabela 1: Distribuição da população por Faculdade/Instituto da UnB ......................51

Tabela 2: Distribuição dos professores de Administração da FACE .........................51

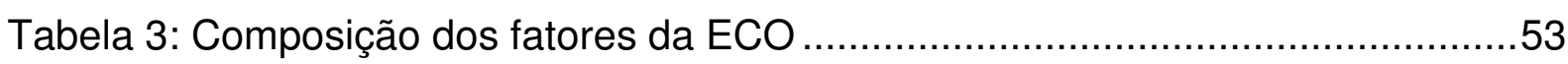

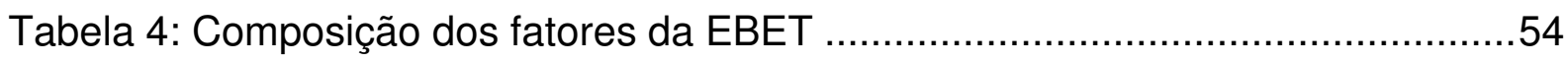

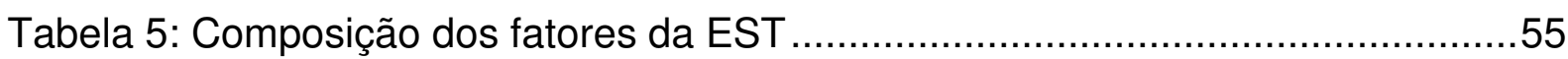

Tabela 6: Distribuição de frequência do comprometimento organizacional ..............60

Tabela 7: Distribuição de frequência do bem-estar no trabalho ...............................61

Tabela 8: Distribuição de frequência da satisfação no trabalho ...............................63

Tabela 9: Preditores da dimensão "afeto positivo" do bem-estar no trabalho ............64

Tabela 10: Preditores da dimensão "afeto negativo" do bem-estar no trabalho ........65

Tabela 11: Preditores da dimensão "realização" do bem-estar no trabalho ...............66

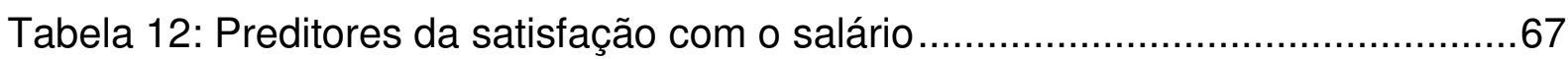

Tabela 13: Preditores da satisfação com os colegas .............................................68

Tabela 14: Preditores da satisfação com a chefia.................................................69

Tabela 15: Preditores da satisfação com as promoções ........................................70

Tabela 16: Preditores da satisfação com a natureza do trabalho.............................71 


\section{LISTA DE ABREVIATURAS E SIGLAS}

ADM - Departamento de Administração

BCE - Biblioteca Central

CAPES - Coordenação de Aperfeiçoamento de Pessoal de Nível Superior

CCA - Departamento de Ciências Contábeis e Atuariais

CIC - Departamento de Ciência da Computação

DAP - Departamento de Audiovisuais e Publicidade

DSC - Departamento de Saúde Coletiva

EBET - Escala de Bem-estar no Trabalho

ECOA - Escala de Comprometimento Organizacional Afetivo

ECOC - Escala de Comprometimento Organizacional Calculativo

ECON - Escala de Comprometimento Organizacional Normativo

ENANPAD - Encontro da Associação Nacional de Pós-Graduação e Pesquisa em Administração

ENM - Departamento de Engenharia Mecânica

EST - Escala de Satisfação no Trabalho

FAC - Faculdade de Comunicação

FACE - Faculdade de Economia, Administração, Contabilidade e Ciência da Informação e Documentação

FAV - Faculdade de Agronomia e Medicina Veterinária

FE - Faculdade de Educação

FEF - Faculdade de Educação Física

FS - Faculdade de Ciências da Saúde

FT - Faculdade de Tecnologia

HUB - Hospital Universitário de Brasília

ICS - Instituto de Ciências Sociais

IE - Instituto de Ciências Exatas 
IGC - Índice Geral de Cursos

IP - Instituto de Psicologia

LDBE - Lei de Diretrizes e Bases da Educação

MEC - Ministério da Educação

NUT - Departamento de Nutrição

PAD - Departamento de Planejamento e Administração

PPGA - Programa de Pós-graduação em Administração

PST - Psicologia Social e do Trabalho

RAC - Revista de Administração Contemporânea

RAE - Revista de Administração de Empresas

RAM - Revista de Administração Mackenzie

RAP - Revista de Administração Pública

Rausp - Revista de Administração da Universidade de São Paulo

REAd - Revista Eletrônica de Administração

SOL - Departamento de Sociologia

SPSS - Statistical Package for the Social Sciences

UnB - Universidade de Brasília

Unifesp - Universidade Federal de São Paulo 


\section{SUMÁRIO}

1 INTRODUÇÃO

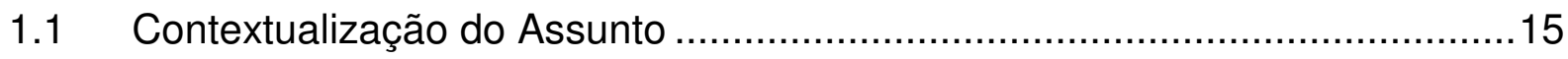

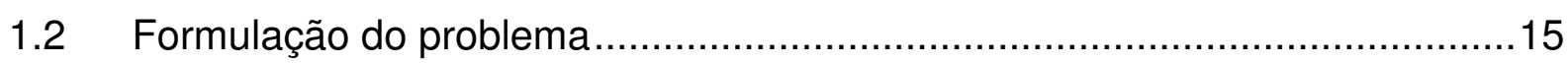

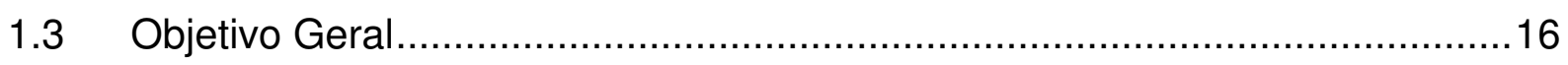

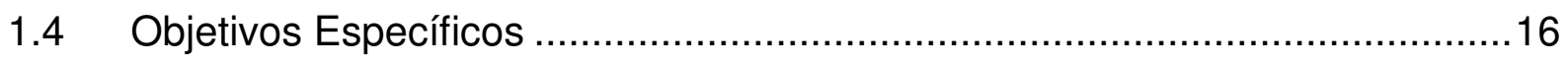

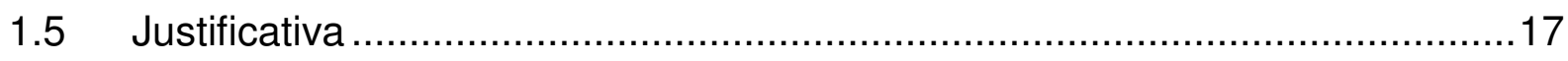

1.6 Métodos e Técnicas de Pesquisa ..........................................................18

1.7 Estrutura e Organização da Monografia .................................................18

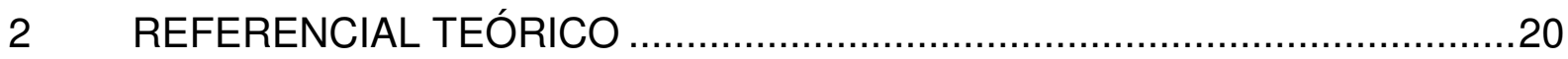

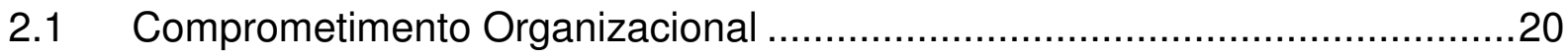

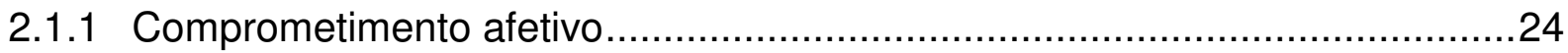

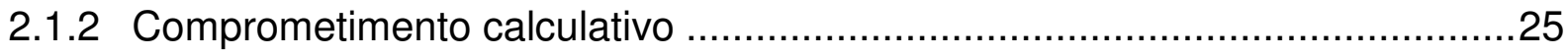

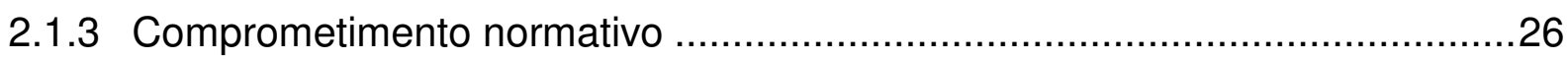

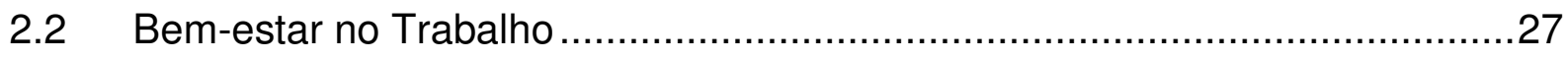

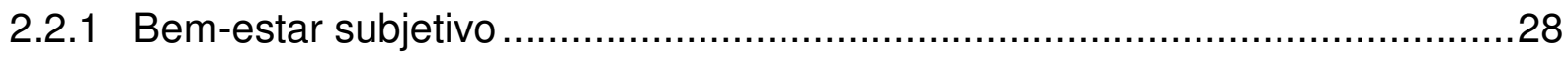

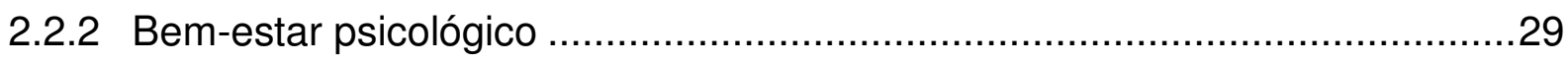

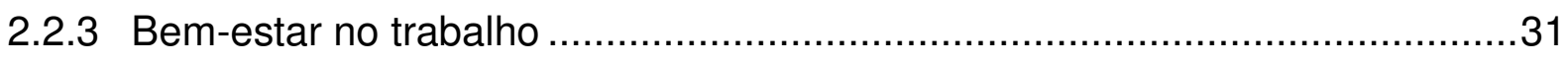

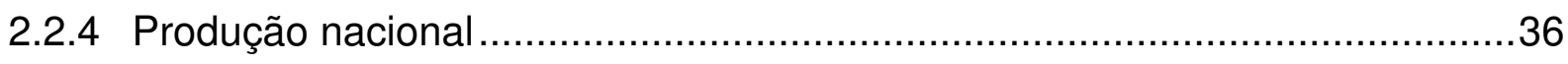

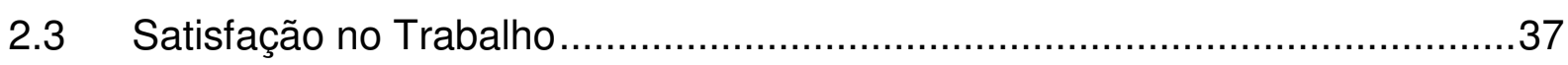

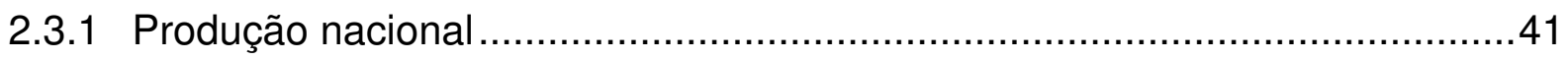

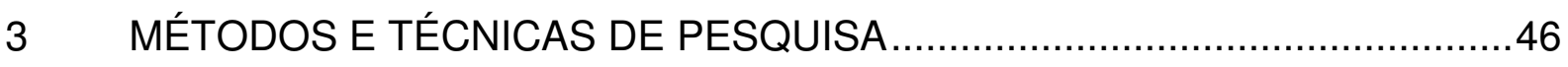

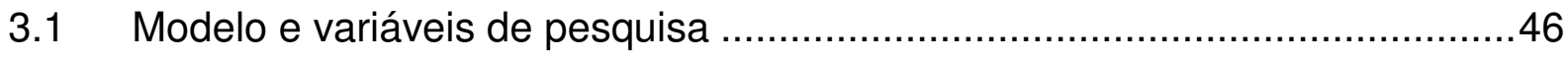

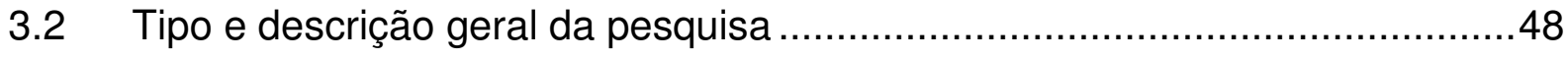

3.3 Caracterização da Universidade de Brasília ...............................................48

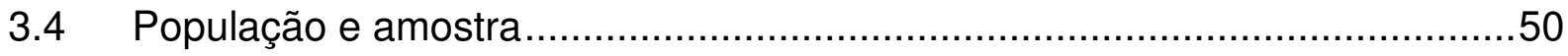




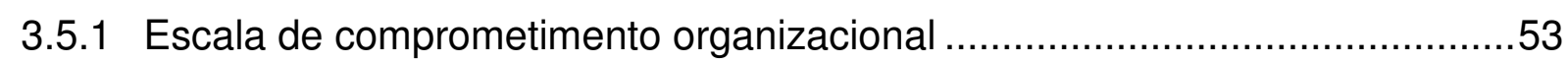

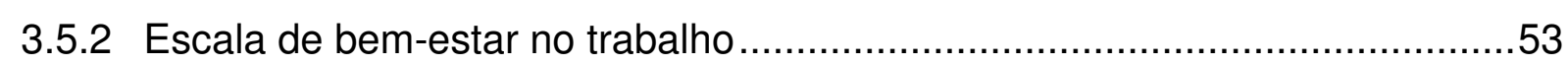

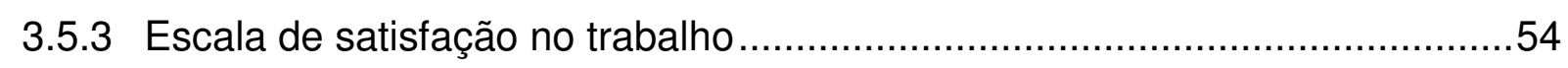

3.6 Procedimentos de coleta e de análise de dados .....................................55

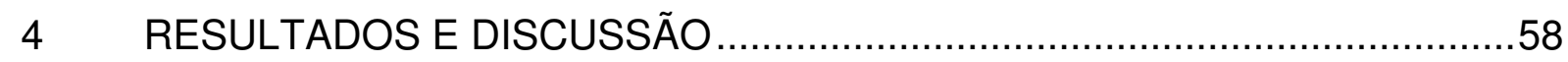

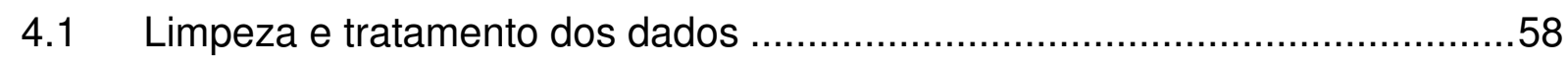

4.2 Identificação do comprometimento organizacional ................................59

4.3 Identificação do bem-estar no trabalho.............................................60

4.4 Identificação da satisfação no trabalho............................................61

4.5 Relações entre comprometimento organizacional, bem-estar no trabalho e

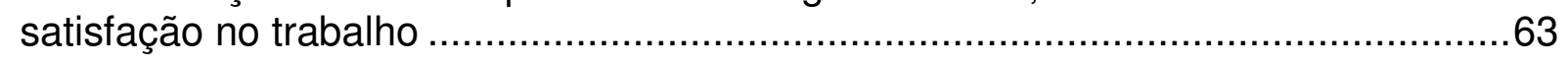

4.5.1 Regressão múltipla tendo como variável dependente a dimensão "afeto positivo" do bem-estar no trabalho.

4.5.2 Regressão múltipla tendo como variável dependente a dimensão "afeto negativo" do bem-estar no trabalho.

4.5.3 Regressão múltipla tendo como variável dependente a dimensão "realização" do bem-estar no trabalho

4.5.4 Regressão múltipla tendo como variável dependente a satisfação no trabalho com o salário. .67

4.5.5 Regressão múltipla tendo como variável dependente a satisfação no trabalho com os colegas 68

4.5.6 Regressão múltipla tendo como variável dependente a satisfação no trabalho com a chefia. 68

4.5.7 Regressão múltipla tendo como variável dependente a satisfação no trabalho com as promoções 69

4.5.8 Regressão múltipla tendo como variável dependente a satisfação no trabalho com a natureza do trabalho. .70

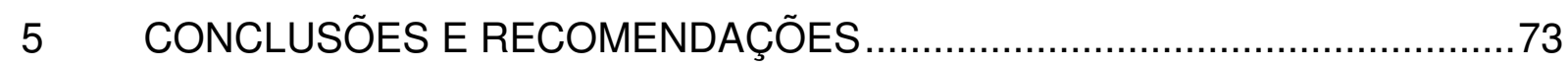

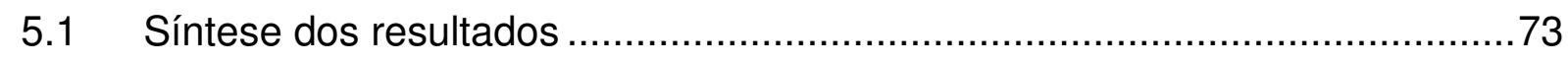

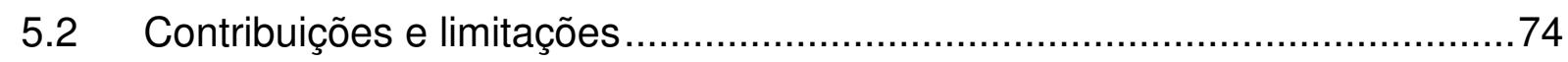


5.3 Recomendações para estudos futuros ................................................. 75

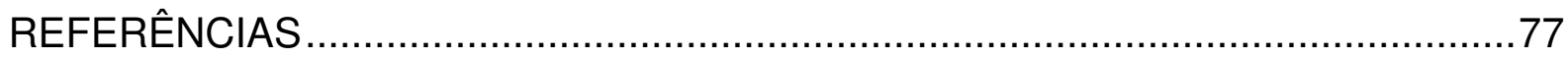

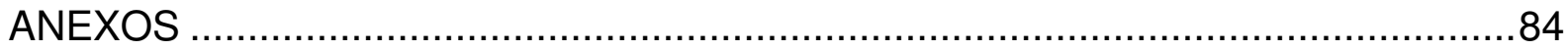

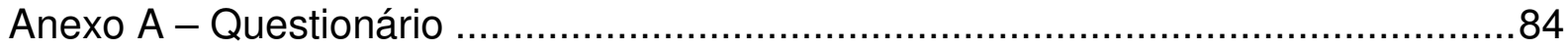




\section{INTRODUÇÃO}

Este estudo analisou a relação entre as variáveis "comprometimento organizacional", "bem-estar no trabalho" e "satisfação no trabalho". Adotou-se dois modelos, no primeiro, a variável independente "comprometimento organizacional" foi relacionada à variável dependente "bem-estar no trabalho" e no segundo, a variável "comprometimento organizacional" permanece como variável independente enquanto que a variável "satisfação no trabalho" aparece como dependente. O objetivo da pesquisa se concentrou em avaliar a influência do comprometimento organizacional dos professores que lecionam disciplinas de Administração na Universidade de Brasília em seu bem-estar e satisfação no trabalho. Dessa forma, verificou-se os melhores preditores do bem-estar no trabalho e da satisfação no trabalho a partir dos modelos propostos.

Neste trabalho, utilizou-se as seguintes definições para os construtos em estudo. Siqueira (2000) entende o comprometimento organizacional como um vínculo psicológico que caracteriza a relação do colaborador com a organização. Siqueira (1995, p. 118) acredita que o comprometimento organizacional afetivo ocorre quando é "desenvolvida uma ligação psicológica, de natureza atitudinal, com a organização". Ainda para a citada autora, o comprometimento organizacional calculativo pode ser constatado na ocorrência de uma avaliação positiva de uma análise custo-benefício, onde o colaborador entende que tem mais a ganhar na empresa do que fora dela. Na base normativa, o vínculo é mantido, pois o colaborador sente que deve algo àquela organização, não acreditando ser justo ou prudente trocá-la por outra.

A variável do bem-estar no trabalho é conceituada por Paschoal e Tamayo (2008) como a prevalência de emoções positivas no ambiente de trabalho e a percepção do indivíduo de que expressa e desenvolve seus potenciais e habilidades no trabalho, avançando no alcance das metas que estabeleceu para sua vida. A partir dessa conceituação, o bem-estar no trabalho abarca tanto aspectos afetivos (emoções e humores) quanto cognitivos (percepção de expressividade e realização). Isso permite que o conceito possa ser aplicado em diferentes contextos de trabalho, organizacionais ou não. 
A satisfação no trabalho é uma variável multifatorial, onde os fatores frequentemente estudados são a satisfação com a natureza do trabalho, com o salário, com o sistema de promoções, com os colegas e com os gerentes. Para Tamayo (1998), a satisfação no trabalho parece encontrar a sua fonte principal na natureza mesma do trabalho, no grupo, nas condições de trabalho e no clima em que ele é realizado. Para Siqueira (1995, p. 160), o construto pode ser definido como "um elo afetivo com o trabalho, que se desenvolve a partir de cognições elaboradas pelo empregado sobre sua relação de troca social com o sistema".

\subsection{Contextualização do Assunto}

Uma quantidade expressiva de estudos vêm sendo realizada com o objetivo de desvendar cada vez mais a natureza e as peculiaridades das relações existentes no ambiente de trabalho, seja a relação colaborador e organização, seja o significado e o impacto da atividade laboral na vida do colaborador. Por exemplo, Siqueira e Gomide Júnior (2004) ao explicarem o construto satisfação no trabalho, ressaltam a importância do vínculo afetivo do colaborador com a organização. Dessa forma, os estudos realizados pelos autores apontam que os colaboradores com níveis altos de contentamento com o trabalho apresentam baixo nível de rotatividade e absenteísmo, refletindo também melhor desempenho e produtividade.

A pesquisa e o estudo sobre nível de bem-estar no trabalho, comprometimento organizacional e satisfação no trabalho vem sendo realizada com êxito na área de psicologia organizacional. No entanto, desconhece-se um modelo que explore as três variáveis no mesmo estudo e no contexto da docência universitária, especialmente no curso de Administração.

\subsection{Formulação do problema}

Siqueira e Gomide Júnior (2004, p. 302) afirmam que "existem evidências de que pessoas com níveis altos de contentamento com o trabalho são também as que menos planejam sair das empresas onde trabalham". Esse vínculo afetivo com o 
trabalho realizado é aferido pelos cinco fatores que integram o conceito teórico de satisfação, a saber: chefia, colegas, salário, promoções e o próprio trabalho.

Resultados de pesquisa têm revelado ainda que o indivíduo satisfeito
tende também a manter em níveis altos o seu envolvimento com o
trabalho que realiza e a se comprometer com a organização que o
emprega. Portanto, satisfação, envolvimento e comprometimento são
vínculos que tendem a apresentar níveis significativos de correlação
positiva entre si. Isso significa, por exemplo, que se forem avaliados
os níveis de satisfação, envolvimento e comprometimento dos
empregados será possível encontrar entre eles pessoas que estão
satisfeitas e envolvidas com o trabalho e comprometidos com a
organização em que trabalham (SIQUEIRA; GOMIDE JÚNIOR, 2004,
p. 303).

Amaral (2001 apud SIQUEIRA; GOMIDE JÚNIOR, 2004, p. 303) afirma que a variável satisfação no trabalho está fortemente relacionada a outras variáveis relacionadas ao bem-estar, tais como satisfação geral com a vida, estado de ânimo, otimismo e auto-estima. Assim, definiu-se o seguinte problema de pesquisa: professores que apresentam maior nível de comprometimento organizacional possuem maior nível de bem-estar no trabalho e são mais satisfeitos no trabalho?

\subsection{Objetivo Geral}

Avaliar a influência do comprometimento organizacional dos professores que lecionam disciplinas de Administração na Universidade de Brasília em seu bem-estar e satisfação no trabalho, verificando os melhores preditores destes construtos a partir dos modelos propostos.

\subsection{Objetivos Específicos}

- Identificar o comprometimento organizacional nas bases afetiva, calculativa e normativa dos professores que lecionam disciplinas de Administração na Universidade de Brasília;

- Identificar o bem-estar dos professores que lecionam disciplinas de Administração na Universidade de Brasília; 
- Identificar a satisfação no trabalho dos professores que lecionam disciplinas de Administração na Universidade de Brasília.

\subsection{Justificativa}

A motivação para a escolha do tema é oriunda de uma atenta observação realizada ao longo do curso. Muitos professores, apesar da competência e da boa vontade, demonstravam um nível de estresse tão acentuado que comprometia a qualidade das suas aulas bem como a interação com os alunos. Como consequência, constata-se que alguns professores reclamam da remuneração da atividade profissional e das precárias condições de trabalho. Tal conjunção de fatores pode refletir alguma insatisfação, mal-estar, ou mesmo, falta de comprometimento, que trariam, a priori, maus resultados aos alunos e aos próprios docentes. Além disso, como ressaltam Demo e Ponte (2008), os alunos são clientes de escolas e universidades. Daí a extrema relevância em diagnosticar a satisfação, o comprometimento e o bem-estar desses profissionais em tão nobre, porém pouco valorizada, carreira.

Segundo Pimenta e Anastasiou (2002, p. 14), "o ensino é uma prática social complexa, carregada de conflitos de valor e que exige posturas éticas e políticas". Sob esse prisma, nada mais natural que uma série de questionamentos chame atenção. A profissão de professor traz felicidade e realização como atividade laboral? Por que os professores, muitas vezes, têm um emprego paralelo? Eles conseguem mesmo com várias atividades integrar ensino, pesquisa e extensão como previsto pela Lei de Diretrizes e Bases da Educação Nacional (LDBE)? A sala de aula e a relação com outros professores é realmente gratificante? Muitas dessas perguntas ainda ficarão sem resposta. A partir da delimitação do tema, escolheu-se investigar a presente questão: professores que apresentam maior nível de comprometimento organizacional possuem maior nível de bem-estar e são mais satisfeitos no trabalho?

Tal questionamento se torna cada vez mais importante, principalmente no contexto da Universidade de Brasília, considerando o papel estruturador do trabalho no processo de construção da identidade do profissional e, ainda, que os últimos 
editais para contratação vêm apresentando certa restrição, ou seja, passou-se a exigir do professor a ser contratado um regime de dedicação exclusiva. Para tanto, os docentes precisam se sentir bem em seu ambiente de trabalho, onde passarão, ao menos um terço de seu tempo. O Edital $n^{\circ} 479 / 2009$, publicado em $1^{\circ}$ de abril de 2009 apresentou as disposições do concurso público para provimento de vaga no cargo de professor adjunto e professor assistente da UnB. Aquele, iniciando com remuneração de $R \$ 6.497,15$ enquanto que este com $R \$ 3.997,08$ e ambos com regime de dedicação exclusiva.

Demo (2008) já afirmara que o primeiro objetivo de qualquer organização, ou instituição, é primar pelo bem-estar de seus colaboradores. Da mesma forma, é importante para a organização ter colaboradores satisfeitos e comprometidos. Por conseguinte, a idéia desta pesquisa foi investigar as relações entre comprometimento organizacional, bem-estar e satisfação no trabalho.

\subsection{Métodos e Técnicas de Pesquisa}

O trabalho consiste em um estudo explicativo, quantitativo e transversal. $O$ meio utilizado para a consecução dos objetivos se deu a partir da aplicação de questionários cientificamente validados aos professores que lecionam ao menos uma disciplina de Administração na Universidade de Brasília.

A amostra é caracterizada como não-probabilística por conveniência. Os dados foram coletados pela própria pesquisadora nos meses de agosto, setembro e outubro de 2009. Os questionários passaram pelas análises estatísticas descritivas, e em seguida procedeu-se às análises de regressão linear para identificar a relação entre as variáveis e, por fim, atingir os objetivos propostos.

\subsection{Estrutura e Organização da Monografia}

O presente estudo está assim estruturado para melhor compreensão do assunto: 
A fundamentação teórica do estudo, composta pela revisão de literatura das variáveis que compõem a pesquisa, quais sejam: bem-estar no trabalho, comprometimento organizacional e satisfação no trabalho, compõe o capítulo 2.

O capítulo 3 apresenta o método de pesquisa, cobrindo sua descrição, bem como a descrição da amostra, apresentando também os instrumentos utilizados, os procedimentos de coleta e análise dos dados e concluindo com o perfil da instituição estudada.

A apresentação e a discussão dos resultados são abordadas no capítulo 4.

Por fim, o capítulo 5 é destinado às conclusões e recomendações, apresentando a síntese dos principais resultados, as contribuições e limitações da pesquisa bem como a agenda para estudos futuros. 


\section{REFERENCIAL TEÓRICO}

A revisão da literatura apresenta a fundamentação teórica, de modo que a investigação da problemática seja consistente. O referencial teórico é estruturado em três tópicos onde se apresenta o estado da arte das variáveis da pesquisa, sendo em primeiro lugar abordada a variável independente de pesquisa, qual seja, o comprometimento organizacional. Em segundo lugar as variáveis dependentes, a saber, bem-estar no trabalho e satisfação no trabalho.

As variáveis dependentes também contaram com subtópicos destinados à revisão da produção nacional dos últimos cinco anos, ou seja, desde 2004 até 2008, em ordem cronológica no afã de se registrar a evolução de pesquisas sobre os temas. Optou-se por realizar essa revisão em periódicos científicos das áreas de Administração e Psicologia avaliados com menção superior pela Coordenação de Aperfeiçoamento de Pessoal em Nível Superior (CAPES), a saber, as revistas Revista de Administração Contemporânea (RAC), Revista de Administração da Universidade de São Paulo (Rausp), Revista de Administração de Empresas (RAE), Revista de Administração Pública (RAP), Revista de Administração Mackenzie (RAM), Revista Eletrônica de Administração (REAd), Psicologia: reflexão e crítica, Psicologia em Estudo, Psicologia: teoria e pesquisa, Avaliação Psicológica e Revista da Sociedade de Psicologia do Triângulo Mineiro. Os anais do Encontro da Associação Nacional de Pós-Graduação e Pesquisa em Administração (ENANPAD) também foram pesquisados no mesmo período, ou seja, de 2004 a 2008.

\subsection{Comprometimento Organizacional}

O vínculo do colaborador e da empresa já vem sendo estudado desde o século XX, despertando um interesse maior com o início do processo de globalização. Atribui-se a uma motivação econômica, em um contexto de crescente competitividade entre organizações, 0 incremento de estudos voltados para 0 elemento humano nas organizações. 
Siqueira e Gomide Júnior (2004) ressaltam que a palavra comprometimento, no senso comum, é amplamente utilizada para se referir ao relacionamento de pessoas, grupos e até mesmo com uma organização. Os autores destrincham o significado da palavra, chegando à conclusão de que ela expressa "uma ação ou ato de comprometer-se, sendo que o próprio ato de comprometer revela a idéia de obrigar por compromisso" (SIQUEIRA; GOMIDE JÚNIOR, 2004, p 313). Assim, um relacionamento com comprometimento se perfaz em uma interação social baseada em uma obrigação ou promessa mais ou menos solenes entre os agentes.

$\mathrm{Na}$ área de comportamento organizacional, o comprometimento organizacional ganhou destaque nos estudos e pesquisas. Demo (2003) ressalta que o comprometimento no trabalho é oriundo da categoria "contratos psicológicos entre organização e empregados", dentro da disciplina de comportamento organizacional. O contrato psicológico, para Wetzel (2001), se perfaz em um contrato implícito, não formal, ocorrendo conforme a percepção do empregado sobre as promessas de direitos e obrigações entre o colaborador e a organização.

Tenbrunsel et al. (2002 apud DEMO, 2003, p. 188) trabalham o construto como um conceito atitudinal, em função de ser "uma variável interveniente ou um elo não observável entre estímulos observáveis e uma resposta observável, incluindo tendências cognitivas e comportamentais". Para os autores, as atitudes são representadas na memória, podendo-se distinguir antecedentes e consequentes afetivos, cognitivos e comportamentais.

Na década de 1970, observa-se o

início da produção de estudos empíricos sobre o tema, principalmente nos EUA. O principal questionamento feito pelos pesquisadores da época era saber quais as principais razões para o absenteísmo e para a rotatividade dentro das organizações, tendo como perspectiva os resultados organizacionais (MARTINS P., 2009, p. 25).

Dessa forma, a busca pela melhoria da produtividade e dos padrões de qualidade aponta para uma atenção mais detalhada aos colaboradores. O nível de comprometimento organizacional do colaborador refletirá atitudes e comportamentos importantes para a organização. Assim,

mantendo o foco da produtividade e, portanto, no desempenho dos colaboradores, as conseqüências atribuídas ao construto, rotatividade e absenteísmo, são as mais citadas. Quando o 
comprometimento do indivíduo é baixo, ele tende a atrasos, fraco desempenho e esforço no trabalho. Por outro lado, o colaborador comprometido vivencia sentimentos positivos de segurança, eficácia e elevada auto-estima (MOWDAY; PORTER; STEERS, 1982 apud MARTINS P., 2009, p. 25).

Nos últimos anos, a qualificação dos colaboradores foi significativa, fazendo surgir no estudo das organizações conceitos novos, tais como empregabilidade e competências. Bastos (1993) relatava essas aceleradas mudanças e transformações, demonstrando a busca das empresas em atrair e manter os colaboradores mais competentes. O que se mantém até então, quando se observa o grande esforço das organizações em captar e reter pessoas melhor qualificadas com prontidão para se comprometer com a organização. Isso fica evidenciado pelos onerosos e complexos processos de recrutamento e seleção de pessoal que buscam prover as organizações com profissionais comprometidos e com desempenho superior. Ratificando essa posição, O'Reilly e Pfeffer (2001) informam que aliado ao dispêndio dos processos de seleção, os programas de retenção de talentos implicam investimentos cada vez maiores decorrentes dos salários competitivos e da variada gama de benefícios oferecidos.

Apesar do número expressivo de estudos realizados, ainda não há consenso na definição do conceito e na maneira como avaliá-lo. Demo (2003) observa que o consenso quanto à dimensionalidade do construto vem crescendo entre os estudiosos, reforçando, portanto, um caráter multidimensional. Ratificando essa posição, Medeiros et al. (2003) acrescenta que o século XX mostrou diversas pesquisas abordando o comprometimento como um construto multidimensional, de modo a entender os indivíduos e seus complexos vínculos com a organização. Dentro desse contexto, a pesquisa de comprometimento organizacional tem evoluído.

Demo (2003) também apresenta as múltiplas bases do construto, como a afetiva (processo de identificação do indivíduo com os objetivos e valores da organização), a calculativa (produto das recompensas e custos percebidos pelo colaborador na condição de integrante da organização), a normativa (conjunto de pressões de normas sociais que definem o vínculo do colaborador com a organização), a sociológica (vínculo que surge das relações de autoridade com o empregador) e a comportamental (conjunto de cognições que guiam os comportamentos que fortalecem o vínculo com a organização). 
Essas diferentes bases têm conduzido a tipologias de comprometimento, como mostram os trabalhos de Meyer, Allen e Smith (1993), que apresentam um modelo tridimensional de comprometimento: afetivo, de continuação e normativo. É importante lembrar o estudo clássico de Gouldner (1960), quando questionou o comprometimento como construto unidimensional, que revelou duas dimensões para o comprometimento, a saber, integração, entendida como o grau em que um indivíduo é ativo e se sente parte, em vários níveis, de uma organização em particular, e introjeção, entendida como o grau em que a própria imagem de um indivíduo inclui uma variedade de características e valores organizacionais aprovados (DEMO, 2003, p. 188).

Segundo Medeiros et al. (2003, p. 190), "na última década, três enfoques conceituais predominaram no estudo do comprometimento organizacional: afetivo, calculativo e normativo". Demo (2003, p. 190) ressalta que os estudos sobre comprometimento "têm se concentrado no foco organizacional e na base afetiva, tanto no Brasil quanto no exterior". A autora sustenta ainda que o vínculo do comprometimento organizacional pode ser baseado em múltiplos processos psicológicos, além de poder ser estudado sob múltiplos focos, tais quais, com a organização, com a carreira e com o sindicato.

No presente estudo, utilizou-se o foco organizacional, contemplando as três bases mais estudadas, a saber, afetiva, calculativa e normativa.

Comprometimento é uma relação forte entre um indivíduo identificado com e envolvido numa organização em particular, e pode ser caracterizado por pelo menos três fatores: estar disposto a exercer esforço considerável em benefício da organização; forte crença e aceitação dos objetivos e valores da organização; forte desejo de se manter membro da organização (PORTER; SMITH, 1970 apud MEDEIROS et al., 2003, p.190).

A caracterização dos colaboradores quanto a estes fatores pode ser entendida da seguinte forma:

empregados com forte comprometimento afetivo permanecem na organização porque eles querem; aqueles com comprometimento instrumental permanecem porque eles precisam e aqueles com comprometimento normativo permanecem porque eles sentem que são obrigados (ALLEN; MEYER, 1990, p. 3).

A Escala de Comprometimento Organizacional nas bases afetiva, calculativa e normativa foi construída e validada por Siqueira (1995, 2000). 


\subsubsection{Comprometimento afetivo}

Para Mowday, Porter e Steers (1982 apud DEMO, 2003) o comprometimento afetivo pode ser definido pelas suas principais características, a saber: crença e aceitação dos objetivos e valores organizacionais; disposição para defender a organização; e desejo de manter o vínculo com ela. Para os autores, este tipo de comprometimento vai além da simples lealdade passiva à organização, perfazendo uma relação ativa onde o colaborador deseja dar algo de si a fim de contribuir para o bem-estar da organização em que trabalha.

Borges-Andrade (1994 apud DEMO, 2003) concebe o comprometimento afetivo como um processo onde o colaborador se identifica e se envolve com uma organização. $O$ autor sugere que popularmente o comprometimento afetivo é bem representado pela expressão "vestir a camisa da organização". Siqueira e Gomide Júnior (2004, p. 316) sintetizam esse entendimento no "desenvolvimento de uma ligação psicológica, de natureza afetiva, com a organização".

Medeiros et al. (1999) concluem que o comprometimento afetivo reflete, no geral, o sentimento de lealdade para com a organização, o significado pessoal, o desejo de permanecer na organização, o esforço em benefício da organização bem como o reconhecimento para com a organização. Por fim, o comprometimento afetivo pode ser expresso como

o desejo de permanecer na organização e [que] seria desencadeado por experiências anteriores de trabalho, especialmente aquelas que satisfizeram necessidades psicológicas do empregado, levando-o a se sentir confortável dentro da organização e competente em seu trabalho ( MEYER; ALLEN; SMITH, 1993 apud DEMO, 2003, p. 192).

Ainda segundo esses autores, os indivíduos que detêm um forte comprometimento afetivo permanecem na organização porque eles o desejam, enquanto que outras pessoas comprometidas sob outros enfoques podem continuar na organização por se sentirem obrigadas através de um sentimento de dívida para com a organização ou simplesmente por constatar um bom resultado em uma análise custo-benefício.

Para Siqueira e Gomide Júnior (2004), os antecedentes do comprometimento organizacional afetivo são características pessoais, características do cargo, microfatores, macrofatores e a percepção de suporte organizacional. Os mesmos 
autores também estudaram as consequências do construto para as organizações, a saber: melhor desempenho, maior esforço no trabalho, menor rotatividade, menos faltas e menos atrasos.

\subsubsection{Comprometimento calculativo}

Segundo Siqueira e Gomide Júnior (2004), enquanto o comprometimento afetivo contempla as ligações afetivas com a organização e insere-se no âmbito da afetividade, tanto o comprometimento calculativo quanto o normativo representam dimensões cognitivas particulares da relação entre colaborador e organização. Os autores ainda sugerem que esses enfoques poderiam ser melhor explicados a partir das relações de troca entre colaborador e organização.

O comprometimento organizacional calculativo torna-se um conceito cognitivo para representar o pensamento do empregado acerca de sua relação de permuta econômica com a empresa, uma vez que compreende crenças relativas a perdas ou custos associados ao rompimento da relação de troca com a organização (SIQUEIRA; GOMIDE JÚNIOR, 2004, p. 318).

Siqueira (2000) sugere que o comprometimento calculativo pode ser vislumbrado pelo ato do colaborador permanecer na organização a partir da motivação de percepções individuais sobre custos/perdas de investimento decorrentes do desligamento da organização. Em outras palavras, a organização contará com o colaborador enquanto ela for atraente para ele. Caso surja outra oportunidade mais convidativa, que aponte um melhor resultado na análise custobenefício, o colaborador tende a abandonar a menos atraente e migrar para a outra que apresenta melhores retornos para ele. Siqueira e Gomide Júnior (2004, p. 318) concebem essa avaliação positiva de resultados a partir da análise de diversos pontos, tais quais: posição alcançada na organização, acesso a certos privilégios ocupacionais, benefícios oferecidos a colaboradores antigos, planos específicos de aposentadoria. Esses resultados são "conseqüência dos investimentos do empregado e, concomitantemente, pela possibilidade percebida de perder, ou de não ter como repor vantagens decorrentes dos investimentos, caso se desligasse da organização". 
Os antecedentes do construto apontados por Siqueira e Gomide Júnior (2004) são a inexistência de ofertas atrativas de novo emprego, o tempo de trabalho na empresa, os esforços investidos no trabalho e as vantagens econômicas no atual emprego. Os autores apresentam também as consequências para as organizações, a saber: baixa motivação, baixo desempenho, menor rotatividade, moderada satisfação no trabalho, moderado envolvimento com 0 trabalho, moderado comprometimento organizacional afetivo e normativo.

\subsubsection{Comprometimento normativo}

Wiener (1982 apud SIQUEIRA; GOMIDE JÚNIOR, 2004, p. 319) identifica o comprometimento organizacional normativo como uma "forte tendência do indivíduo para guiar seus atos por valores culturais internalizados, sem muitas vezes, se dar conta de quão pouco racionais certas ações deles decorrentes possam parecer".

Os colaboradores que são comprometidos normativamente continuam trabalhando para a organização por um sentimento de dívida ou ainda, obrigação. Portanto, se o colaborador permanece na organização porque se sente moralmente vinculado a ela ou aos colegas, verifica-se a presença do comprometimento normativo. Segundo McGee e Ford (1987 apud MEDEIROS, 2003, p. 32), esse tipo de comprometimento é similar a um sacrifício pessoal e é vinculado às pressões normativas oriundas da cultura organizacional sob forma de missão, normas e regras da empresa. Siqueira (2000) afirma que as crenças do colaborador sobre a dívida social para com a organização, ou a necessidade de retribuir um favor, também integram o comprometimento organizacional normativo.

Dessa forma, os colaboradores que possuem alto nível de comprometimento normativo se sentem presos à organização que, por sua vez, possui diferentes formas de fazer com que seus colaboradores se sintam incapazes de abandoná-la. Nessas organizações, existe grande contato entre organização e colaboradores de modo semelhante a uma família com regras de conduta e missão muito fortes, de modo a levar o colaborador à convicção de que a organização necessita dele para continuar obtendo sucesso. Siqueira e Gomide Júnior (2004) afirmam que as 
pressões normativas são advindas da cultura da empresa que determina a ação e o comportamento dos colaboradores na organização.

\subsection{Bem-estar no Trabalho}

O posicionamento de Carneiro e Carvalho (2003) é de que nos últimos anos, a Psicologia Social e Organizacional tem direcionado parte de seus estudos para a saúde do trabalhador, tendo em vista as expressivas mudanças ocorridas no ambiente de trabalho desde o final do século XX. Ademais, segundo Evans e Steptoe (2002), o avanço na obtenção de direitos trabalhistas fez com que os colaboradores permanecessem mais tempo na mesma organização, de modo a obter certa estabilidade, sanando suas necessidades básicas de sustento e segurança, contribuindo para um maior bem-estar geral.

Apesar dessas conquistas, Mäkikangas e Kinnunem (2003) ressaltam que os colaboradores têm passado por significativas mudanças laborais, aumentando seu nível de estresse no trabalho e refletindo prejudicialmente no nível de bem-estar. Dessa forma, cada vez mais os profissionais da Administração por meio de estudos realizados pela Psicologia vêm se conscientizando da importância do bem-estar no trabalho e de seus reflexos na produtividade, no clima organizacional e nos resultados.

Diversos estudiosos conseguiram, após décadas de investigações, instalar o conceito de bem-estar no campo científico da Psicologia e transformá-lo em um dos temas mais enfaticamente discutidos e aplicados para compreender os fatores psicológicos que integram uma vida saudável (SIQUEIRA et al., 2008 apud MARTINS P., 2009, p. 201).

É mister alertar que a pesquisa do bem-estar no contexto organizacional ainda é bem incipiente. Mesmo as pesquisas realizadas sobre o bem-estar geral não apresentam um consenso acerca da definição do construto, devendo-se, portanto, proceder com prudência à análise e à explicação de cada estudo sobre o tema. A tendência dos pesquisadores é identificar a relação entre as emoções vivenciadas pelo colaborador em decorrência do trabalho e como elas afetam a saúde e o desempenho dos profissionais. Cabe ressaltar que a definição de saúde para a Organização Mundial de Saúde corresponde a "um estado de completo bem-estar 
físico, mental e social, e não somente a ausência de enfermidades" (WHO, 1948 apud PAIVA; BORGES, 2009, p. 58).

Diener (2000) pesquisou que os estudos sobre bem-estar surgiram no início dos anos sessenta e que tal temática vem recebendo um crescente interesse. Outras denominações também identificam este construto, tais como felicidade, satisfação, afetos positivos e avaliação subjetiva da qualidade de vida. No presente estudo, adotou-se a denominação bem-estar no trabalho.

Para Albuquerque e Tróccoli (2004), o estudo do bem-estar refere-se à produção acadêmica de investigações acerca da felicidade. No que tange ao bemestar geral, pode-se dividi-lo em duas correntes: a do bem-estar subjetivo e a do bem-estar psicológico, sendo a principal diferença entre elas a concepção de felicidade adotada.

\subsubsection{Bem-estar subjetivo}

A concepção de felicidade a partir do bem-estar subjetivo tem origem na tradição hedônica. A proposta dos autores que se filiam à concepção hedônica de felicidade é que o bem-estar engloba a experiência de prazer e desprazer, ocasionando assim, julgamentos sobre os elementos positivos e negativos da vida.

Albuquerque e Tróccoli (2004) veem o bem-estar subjetivo a partir de três dimensões, a saber, o afeto positivo, o afeto negativo e a satisfação com a vida. Além disso, os autores alertam para o fato de que apresentar um alto nível de bemestar não significa necessariamente a ausência de emoções negativas, mas apenas o predomínio de emoções positivas sobre as negativas. A satisfação com a vida consiste em um julgamento cognitivo da própria vida e inclui as circunstâncias da vida da pessoa e os padrões escolhidos por ela. Portanto, o bem-estar subjetivo é a ocorrência de frequentes afetos positivos, rara experiência emocional negativa e a satisfação com a vida como um todo. Assim, o bem-estar inclui respostas emocionais da pessoa e julgamentos a respeito da sua satisfação com a vida.

As respostas emocionais correspondem a emoções e humores, juntos denominados de afeto, e representam avaliações e reações do indivíduo sobre eventos atuais da sua vida. Julgamentos sobre a 
satisfação com a vida são considerados aspectos cognitivos do bemestar (PASCHOAL; TAMAYO, 2008, p. 12).

As emoções originadas no trabalho estão relacionadas com a saúde do colaborador e afetam não apenas seu desempenho profissional, mas também sua vida pessoal.

No geral, tem-se constatado que as emoções, especialmente aquelas advindas do trabalho, podem gerar tanto efeitos positivos quanto negativos à saúde do trabalhador. Pessoas que freqüentemente sofrem de exaustão emocional, ansiedade e depressão no trabalho, mostram-se insatisfeitas com suas vidas e não conseguem desempenhar a contento suas atividades profissionais (CARTER, 2004 apud GOUVEIA et al., 2008, p. 465).

Outros autores, como Ryan e Deci (2001), acreditam que o bem-estar é formado essencialmente por dois fatores, o cognitivo e o afetivo. O cognitivo é entendido como a satisfação com a vida, permitindo também que o indivíduo possa fazer uma avaliação global de sua própria vida ao passo que o segundo, o afetivo, contempla os componentes emocionais, permitindo a pessoa vivenciar emoções de prazer (positivas) e de desprazer (negativas).

\subsubsection{Bem-estar psicológico}

A outra corrente do bem-estar consiste na idéia do bem-estar psicológico, inspirada na concepção eudaimonica da felicidade. Paschoal e Tamayo (2008) relatam que, para Aristóteles, o objetivo supremo de todo comportamento é a felicidade ou eudaimonia. No entanto, os autores alertam que o termo felicidade em português não corresponde à expressão aristotélica.

A palavra felicidade refere-se à felicidade hedônica, pois ela expressa a experiência subjetiva de afetos positivos e a crença de que a própria vida está satisfatória. Eudaimonia refere-se não somente à felicidade hedônica, mas também à realização do potencial pessoal e das metas fundamentais de vida (PASCHOAL; TAMAYO, 2008, p. 12).

Waterman (1993) acrescenta que o filósofo (Aristóteles) defendia o entendimento de que a eudaimonia era a expressão ativa de virtudes, o conjunto do que cada um tinha de melhor. Assim, "sentimentos de expressividade pessoal e de 
auto-realização seriam elementos centrais e definidores da eudaimonia ou felicidade" (PASCHOAL; TAMAYO, 2008, p. 12).

A corrente do bem-estar psicológico acredita que os fatores fundamentais para a definição do construto foram desprezados pelos estudiosos da corrente hedônica. Exemplo disso é o fato de Riff (1989) entender o bem-estar como o funcionamento positivo global do indivíduo.

Um indivíduo com alto bem-estar é aquele que apresenta altos
índices de auto-aceitação (atitudes positivas do indivíduo em relação
a si mesmo), relação positiva com os outros (satisfação e confiança
na relação com os outros), autonomia (autodeterminação,
independência e auto-regulação do comportamento), controle do
ambiente (habilidade do indivíduo para escolher ou criar situações
adequadas às condições pessoais), propósito na vida (senso de
direção que contribui para a percepção de que a vida é significativa)
e crescimento pessoal (desenvolvimento do potencial do indivíduo e
da sua expansão como pessoa). Os seis elementos propostos
definem o bem-estar psicológico tanto teórica quanto
operacionalmente (RIFF; KEYES, 1995 apud PASCHOAL; TAMAYO,
2008, p. 13).

Segundo Ryan e Deci (2001), esses seis elementos são antecedentes e não definidores do bem-estar psicológico. Dessa maneira, com o intuito de não se limitarem à visão hedônica e também de não confundirem o construto com seus antecedentes, sugeriram que o bem-estar fosse considerado não somente como prevalência de afeto positivo e satisfação com a vida, mas também abarcando a idéia de vitalidade e saúde mental. Esse entendimento inspirou outros estudos que examinaram

o efeito da autonomia para a execução de tarefas sobre afetos positivos e vitalidade. Os resultados mostraram que quando 0 indivíduo era pressionado a realizar uma atividade, o término da mesma associava-se com afeto positivo, mas não com vitalidade. Por outro lado, quando o indivíduo tinha autonomia, a conclusão da tarefa associava-se tanto aos afetos positivos quanto à vitalidade (NIX, 1999 apud PASCHOAL; TAMAYO, 2008, p. 13).

Nessa linha, há o estudo de Ryan e Deci (2001) argumentando que o bemestar pode ser melhor explicado como um fenômeno multidimensional que contempla aspectos das concepções tanto hedônicas como eudaimonicas de felicidade, portanto, as experiências de prazer e de expressividade/realização são fenômenos diferentes, mas que, no entanto, constituem o bem-estar. 
Para Waterman (1993), o indivíduo pode ter experiências de expressividade pessoal e auto-realização quando se experimenta:

- um intenso envolvimento com um empreendimento;

- um sentimento de uma adequação especial na execução de atividades que não fazem parte de tarefas cotidianas;

- um sentimento intenso de estar vivo;

- uma sensação de estar completo quando engajado em determinadas atividades;

- uma sensação de que fez o que realmente queria fazer, e

- a percepção de que consegue expressar seu verdadeiro eu.

Concluindo, no entendimento desse autor, a expressividade pessoal e a autorealização referem-se primordialmente à experiência individual de realização dos próprios potenciais, na forma de desenvolvimento de habilidades e talentos e/ou de avanço de seus propósitos na vida.

\subsubsection{Bem-estar no trabalho}

Os autores que se filiam à corrente do bem-estar organizacional adotam o modelo de Warr (1987 apud PASCHOAL; TAMAYO, 2008) sobre saúde mental para trabalhar com o bem-estar laboral, definindo e operacionalizando o construto. Esse modelo considera

o funcionamento positivo integrado da pessoa e propõe cinco dimensões para a definição da saúde mental: afeto, aspiração, autonomia, competência e funcionamento integrado. Neste modelo, a dimensão afeto refere-se às emoções e humores. A aspiração diz respeito ao interesse do indivíduo pelo seu ambiente e por atividades pessoalmente significativas. A autonomia refere-se ao grau em que a pessoa consegue resistir a pressões do ambiente. A dimensão competência refere-se à habilidade do indivíduo para enfrentar com sucesso as demandas e os problemas do dia a dia. Finalmente, 0 funcionamento integrado refere-se ao funcionamento do indivíduo como um todo e à múltipla relação entre os outros quatro componentes apontados (WARR, 1987 apud PASCHOAL; TAMAYO, 2008, p. 14).

O modelo de Warr (1987 apud PASCHOAL; TAMAYO, 2008, p.14) foi utilizado por Van Horn et al. (2004) no afã de apresentar uma estrutura do bem-estar 
no trabalho embasada na tradição do bem-estar psicológico. O autor valeu-se também da teoria de Riff (1989) sobre o bem-estar geral. Esse estudo, realizado com uma amostra de professores holandeses, partiu da idéia de que o bem-estar no trabalho incluiria aspectos afetivos, motivacionais, comportamentais, cognitivos e psicossomáticos. Foram propostas cinco dimensões para o entendimento do construto, a saber, dimensão afetiva, bem-estar profissional, bem-estar social, cansaço cognitivo e dimensão psicossomática.

As variáveis afeto (frequência de sentimentos e emoções, como otimista e alegre), exaustão emocional (composta por três dimensões clássicas: exaustão emocional, despersonalização e diminuição da realização pessoal), satisfação no trabalho (referente ao quanto o trabalhador está satisfeito com os colegas, com a organização e com a própria atividade do trabalho) e comprometimento organizacional (engloba a identificação e o envolvimento do trabalhador com a organização) compõem a dimensão afetiva.

A dimensão bem-estar profissional trabalha com o aspecto motivacional da estrutura proposta, compreendendo variáveis como: autonomia (liberdade do colaborador para adotar suas próprias decisões no trabalho), aspiração (busca de desafios no trabalho) e competência profissional (percepção do colaborador de que é capaz de lidar de forma eficaz com os problemas do trabalho).

A dimensão bem-estar social trata o aspecto comportamental do bem-estar no trabalho, incluindo dois tipos de conceito, a saber: a despersonalização oriunda da proposta de esgotamento profissional, porém atinentes a atitudes negativas ou indiferentes em relação aos colegas de trabalho; e a qualidade das relações sociais na organização que, por sua vez, inclui a percepção do indivíduo de ser procurado pelos colegas na organização. Inclui também, segundo Van Horn et al. (2004), a percepção do colaborador ser procurado pelos colegas para conselhos e suporte.

A dimensão cansaço cognitivo consiste no aspecto cognitivo do bem-estar no trabalho, referindo-se ao funcionamento cognitivo do colaborador, em especial ao quanto ele consegue processar novas informações e concentrar-se no trabalho.

Por fim, a dimensão psicossomática aborda a presença ou a ausência de queixas psicossomáticas, tais como dores de cabeça e de estômago. Em suma, o bem-estar no trabalho seria um construto muito amplo e multidimensional.

Ainda, segundo Van Horn et al. (2004), o teste realizado foi confirmado e conseguiu demonstrar, também, que os fatores estavam relacionados entre si. Além 
disso, a dimensão afetiva foi a mais representativa do construto, sendo considerada o aspecto central do bem-estar laboral. Ademais, entre as quatro variáveis pertencentes à dimensão afetiva, o afeto operacionalizado como emoções no trabalho, foi o construto que obteve maior representatividade. O pesquisador acredita que seus estudos indicam que o bem-estar é especialmente refletido no estado emocional do trabalhador.

Paschoal e Tamayo (2008) tecem algumas considerações sobre os estudos realizados por Van Horn et al. (2004).

Primeiramente, a definição de bem-estar laboral adotada é ampla e composta de poucos aspectos que possam diferenciá-la de outros conceitos relativos à Psicologia Organizacional. Muitos outros construtos podem ser considerados como uma avaliação positiva do contexto do trabalho, como é o caso da percepção de justiça e da percepção positiva de clima social no trabalho. Afirmar que o bemestar laboral possui dimensões afetiva, motivacional, comportamental, cognitiva e psicossomática também não o diferencia de outros conceitos; pelo contrário, aumenta as interseções com construtos diversos. Em segundo lugar, a proposta de se considerar o funcionamento positivo do sujeito no trabalho faz com que o bemestar laboral torne-se uma área de estudo e não uma variável. Desta forma, poderia ser estabelecida uma série de relações causais entre as dimensões propostas (PASCHOAL; TAMAYO, 2008, p. 15).

Na opinião de Daniels (2000), os pesquisadores que adotaram a abordagem do bem-estar psicológico no contexto do trabalho definem e operacionalizam o bemestar laboral de modo a misturar o bem-estar em si com seus possíveis antecedentes cognitivos. A alternativa proposta pelo citado autor, seria considerar apenas aquele que tem se mostrado o aspecto mais relevante e central do bemestar, ou seja, o afeto. Esse autor, afirma que o bem-estar afetivo se perfaz em uma experiência cumulativa de afetos, relativa a domínios específicos da vida e, por causa disso, poderia ser considerada em relação ao trabalho. Ratificando essa posição, Paschoal e Tamayo (2008) sustentam que os afetos nesta proposta correspondem às emoções e humores vivenciados pelo trabalhador. Afeto na literatura organizacional muitas vezes se relaciona com outros dois construtos, como humor e emoções.

O humor no trabalho tem sido concebido como estados emocionais dificilmente identificados com um estímulo particular e que apresentam maior duração e consistência que emoções específicas. As emoções costumam ser tratadas como intensas, associadas a estímulos específicos, além de serem descritas sob forma discreta, 
como por exemplo, raiva e medo (PAYNE, 2001 apud PASCHOAL; TAMAYO, 2008, p. 16).

Segundo Van Horn et al. (2004), a dimensão afetiva do bem-estar laboral é composta por afetos (emoções), comprometimento organizacional, exaustão emocional e satisfação. Apesar do referido autor entender a satisfação no trabalho como um elemento definidor de bem-estar laboral, Paschoal e Tamayo (2008) acreditam que a satisfação no trabalho poderia ser melhor entendida como um construto relacionado a ele.

O posicionamento de Daniels (2000) é quase singular uma vez que ele sinaliza a identificação do que é central neste construto, procurando estabelecer seus limites no afã de evitar a interseção com conceitos que podem ser antecedentes ou consequentes do mesmo. Ele prefere trabalhar com as respostas do indivíduo nas experiências oriundas das interações do ambiente de trabalho e das características pessoais para encontrar sua definição do construto. Assim, para esse autor, o bem-estar deve ser entendido como a prevalência das emoções positivas no ambiente laboral. Esse entendimento ganha outros adeptos como Warr (1987) que passam a definir o construto unicamente em termos afetivos (humores e emoções).

Mais recentemente, porém, [Warr] passa a defender dois elementos
centrais no bem-estar laboral: o primeiro embasado na felicidade
hedônica e correspondente aos sentimentos de prazer vivenciados
pelo indivíduo e o segundo relativo a aspectos eudaimonicos, como o
desenvolvimento de atributos pessoais, exploração do próprio
potencial, realização e expressão de si mesmo (PASCHOAL;
TAMAYO, 2008, p. 16).

No entanto, no âmbito nacional, a literatura se desenvolve com Paz (2004) apresentando uma proposta para o construto mais voltada para o contexto organizacional, considerando aspectos situacionais que seriam indissociáveis do construto. Ela passa a trabalhar com dois pontos principais: gratificação e desgosto. O primeiro contempla a percepção do colaborador sobre valorização do trabalho (percepção de que o trabalho é importante para si mesmo, para a organização e para a sociedade), reconhecimento pessoal (ser admirado e recompensado por sua competência), autonomia (liberdade para executar o trabalho no seu estilo pessoal), expectativa de crescimento (possibilidades de desenvolvimento pessoal e profissional), suporte ambiental (percepção de segurança, apoio material, 
tecnológico e social), recursos financeiros (justa relação de troca entre trabalho realizado e salário recebido) e orgulho de pertencer à organização. A referida autora entende o desgosto como reflexo do mal-estar do colaborador, consistindo basicamente na oposição da gratificação.

Porto e Tamayo (2003) complementam esse entendimento ressaltando que o trabalho contribui criando certa auto-estima, saúde mental e convívio social. Nesse sentido, Tamayo (2004) vislumbra no tempo dedicado ao trabalho um componente fundamental para se construir e desenvolver o bem-estar pessoal e a própria felicidade. Dessa forma, o trabalho atende ao desejo humano pela busca do bemestar a partir do momento em que o colaborador se vê na condição de um membro produtivo da sociedade e cumprindo seu objetivo de vida, segundo Morin (2001).

Entretanto, na visão de Kirschenbaum (2000), quando o colaborador se encontra em um trabalho onde sofre constantes pressões, frequentes situações de fracasso e ameaças de desemprego, acaba desencadeando o aumento de emoções negativas, uma vez que suas necessidades não são atendidas, ocasionando insatisfação com a atividade que realizam e queda nos níveis de bem-estar.

A partir desses estudos, parece possível o bem-estar explicar ou se relacionar com a satisfação no trabalho.

No entanto, a produção teórica e a pesquisa empírica sobre esse construto ainda são escassas. Grande parte dos estudos dedica-se a analisar o bem-estar geral, desvinculado de qualquer contexto, como ressaltado por Paschoal e Tamayo (2008) que optaram por vincular o construto ao trabalho.

Nesse sentido, havia uma lacuna quanto à existência de instrumentos validados e confiáveis para a aferição do construto especificamente no contexto das atividades laborais. A Escala de Bem-Estar no Trabalho (EBET) validada por Paschoal e Tamayo (2008) sanou por ora essa carência, de modo que para a presente pesquisa considerou-se esse modelo entendendo o construto composto por uma dimensão afetiva (emoções e humores no trabalho) e uma dimensão cognitiva (percepção de expressividade e realização pessoal no trabalho), contemplando pontos principais da abordagem hedônica e da abordagem eudaimonica. 


\subsubsection{Produção nacional}

Gomide Júnior e Hernandez (2005) estudaram o bem-estar no trabalho a partir de estudos realizados na Universidade Federal de Uberlândia. Averiguaram que esses estudos analisavam primordialmente os impactos das variáveis bem-estar subjetivo e o suporte social na determinação de critérios organizacionais e no contexto do trabalho, como produtividade, absenteísmo e rotatividade. Os autores concluíram que os fatores do ambiente de trabalho determinam mais os níveis de bem-estar no trabalho do que os fatores pessoais do colaborador.

Paschoal e Tamayo (2008) construíram e validaram a Escala de Bem-estar no Trabalho (EBET). A EBET contou com 3 fatores, a saber: afetos positivos, afetos negativos e realização/expressividade. A validação obteve bons parâmetros psicométricos tanto para a aplicação em organizações quanto para o uso em estudos acadêmicos.

Siqueira e Padovam (2008) revisaram os conceitos de bem-estar subjetivo e bem-estar psicológico e apresentaram com mais ênfase a concepção do bem-estar laboral, ou seja, no ambiente de trabalho. As autoras enfatizam a importância da psicologia positiva como meio para se atingir maiores níveis de bem-estar, bem como prevenir patologias. Concluem que o bem-estar geral e no trabalho estão relacionados a uma série de fatores sociais, também no que se refere ao ambiente organizacional, assim como a aspectos internos da organização como responsabilidade sócio-ambiental, adoção de práticas de governança corporativa e políticas em prol dos colaboradores.

Gouveia et al. (2008) adaptaram a Job Related Affective Well-Being Scale para a realidade brasileira. Os autores identificaram dois principais fatores (afetos positivos e afetos negativos), divergindo assim, da escala original que contava com quatro fatores, obtidos a partir do cruzamento de prazer e excitabilidade. Essa diferença foi atribuída ao fato de cada estudo ter adotado procedimentos estatísticos diversos. Os autores não verificaram dependência entre o bem-estar afetivo no trabalho, o gênero e a idade.

Paiva e Borges (2009) investigaram o ambiente laboral de uma organização do setor bancário, bem como o bem-estar de seus colaboradores. Basearam seus estudos no modelo ecológico de saúde mental. Estudaram a saúde mental do 
bancário levando em consideração suas condições no ambiente de trabalho. Ainda que os resultados tenham apontado haver relação entre o ambiente de trabalho e a saúde mental do colaborador, o modelo adotado não explicita o que se deve fazer para promover o bem-estar e minimizar as tendências depressivas dos colaboradores. Por fim, boas condições de trabalho refletiram positivamente na saúde mental.

Os cinco artigos apresentados foram elaborados no contexto do setor público. Dos cinco artigos apresentados, quatro foram pesquisas quantitativas, onde cada um deles aplicou uma escala distinta de bem-estar. Dois deles validaram escalas sobre bem-estar no trabalho, os outros dois dedicaram-se à elaboração de estudos relacionais. Por fim, um artigo trabalhou o conceito de bem-estar em razão da inexistência de consenso para o conceito do construto.

\subsection{Satisfação no Trabalho}

A satisfação no trabalho é uma variável importante para os estudos organizacionais. Staw e Ross (1985) ressaltam que esta é uma das variáveis mais comumente estudadas em Psicologia Organizacional. Já em 2006, Valle (2007) identificou 15.600 publicações, em língua portuguesa, entre artigos, dissertações, teses, apresentações em congressos, entre outros, relacionados direta ou indiretamente à satisfação no trabalho.

A posição de destaque ocupada por satisfação no trabalho decorre, em grande parte, de suposições elaboradas por gestores e pesquisadores a respeito do seu papel determinante sobre os comportamentos dos empregados considerados relevantes para organizações. Com certeza, foram os testes empíricos de tais suposições as principais forças impulsionadoras do grande volume de estudos relacionando satisfação a diferentes critérios da conduta no trabalho. Os pressupostos subjacentes a essas investigações são essencialmente econômicos, quais sejam, de que podem se reduzir os custos envolvidos com a força de trabalho e aumentar os lucros das empresas por meio da manutenção de um contingente de trabalhadores satisfeitos e, conseqüentemente, estável na organização, produtivo e freqüente no trabalho (SIQUEIRA; GOMIDE JÚNIOR, 2004, p. 302).

Martinez (2002) explica que no século XX, o construto satisfação era relacionado ao processo motivacional, tendo, portanto, certa ligação com as teorias 
relacionadas ao comportamento no trabalho. Eis as principais teorias: teoria da hierarquia das necessidades de Maslow, de 1970, a teoria X e Y elaborada por McGregor em 1960 e a teoria dos dois fatores de Herzberg, Mausner e Snyderman, de 1959. Sob esse prisma, os administradores começaram a defender a satisfação como causa de comportamentos dos seus colaboradores no trabalho refletindo assim, no desempenho, produtividade, rotatividade e absenteísmo. Taylor (1947 apud MARTINS M.; SANTOS, 2006, p. 196) relacionava aspectos como fadiga e salário à satisfação e à produtividade.

Nesse sentido, Katz e Kahn (1978) afirmam que até a década de 1960 o construto satisfação foi empregado preponderantemente como variável preditora de indicadores comportamentais para a efetividade de qualquer organização, sendo utilizada, portanto como variável antecedente de cidadania organizacional.

Da década de 1980 em diante, a satisfação passou a ser entendida como uma atitude, capaz de predizer diversos comportamentos no trabalho. Jackson e Corr (2002) notavam que diversos modelos de satisfação no trabalho eram propostos e investigados empiricamente. Na maioria dos estudos, o construto era entendido como uma variável de atitude, detentora de componentes afetivos e cognitivos.

Atitude [pode ser definida] como uma predisposição aprendida para responder de maneira consistente, favorável ou desfavoravelmente, com respeito a um dado objeto, sendo composta por crenças, afeto, intenções comportamentais e comportamento (AJZEN; FISHBEIN, 1980 apud VALLE, 2007, p. 1).

Campbell (1999) acreditava que as atitudes derivavam de crenças e que, dessa forma, as atitudes poderiam ser consideradas como poderosas influências sobre o comportamento e os processos de aprendizagem sendo, portanto, disposições para agir, decorrentes de conceitos, informações e emoções.

A satisfação no trabalho [é entendida] como um estado emocional agradável resultante da avaliação que o indivíduo fez de seu trabalho e que resulta da percepção da pessoa sobre como este satisfaz ou permite satisfação de seus valores importantes no trabalho (LOCKE, 1976 apud VALLE, 2007, p. 2).

Valle (2007) ressalta que se pode observar nessa conceituação dois componentes importantes, quais sejam, o cognitivo e o afetivo ou emocional. $O$ componente cognitivo se refere ao que o indivíduo pensa e às suas opiniões acerca 
do trabalho. Ao passo que o componente afetivo ou emocional representa quão bem o colaborador se sente em relação a um trabalho, entendendo que a satisfação no trabalho é baseada parcialmente no que o colaborador pensa e parcialmente no que o colaborador sente.

Apesar do empenho dos pesquisadores, não há consenso entre eles sobre a definição e a natureza do construto satisfação no trabalho. Na visão de Marinho (1988), há uma tendência em caracterizar o construto de acordo com uma natureza afetiva, ainda que o próprio autor vislumbre um traço disposicional.

Nessa mesma linha, segundo Staw e Ross (1985), o construto pode ser definido como uma característica individual de natureza disposicional. Para Kahn (1980 apud MARTINS P., 2009, p. 45) a satisfação é resultante das experiências pessoais vividas no ambiente organizacional, sendo projetadas para a vida social do colaborador. Com uma visão mais sucinta, Weiss (2002) conceituou o construto como um julgamento positivo ou negativo que um indivíduo possui sobre o seu trabalho ou determinada situação de trabalho. Spector (2000 apud VALLE, 2007, p.3) expõe que na maior parte das pesquisas sobre comportamento organizacional, a variável satisfação no trabalho foi apresentada como um escore entre diversos itens de uma escala de satisfação (satisfação global) ou um escore sobre múltiplas facetas.

\begin{abstract}
A afirmação subjacente a este conceito é que um único escore (ou gama de escores de facetas) é uma representação completa de como o indivíduo se sente sobre o seu trabalho (em termos de satisfação). Entretanto, há a necessidade de clarificação desta distinção e das relações entre os níveis de satisfação global e de facetas (2000 apud VALLE, 2007, p. 3).
\end{abstract}

Valle (2007) afirma, também, que a maioria dos determinantes do construto (facetas) inclui sistemas de recompensas, fatores como distribuição e centralização de poder, diferenças individuais como auto-estima e a necessidade de realização. Kabanoff (1980) acredita que tais resultados evidenciam uma relação próxima entre o trabalho e a vida familiar. Hazan e Shaver (1990) ressaltam a influência entre o trabalho e os vínculos afetivos do colaborador.

Dessa forma, entende-se que a satisfação no trabalho já foi estudada tanto como uma variável preditora quanto causal em muitos estudos. Outros estudos investigaram a relação entre satisfação com variáveis relacionadas ao trabalho e ao colaborador. A relação entre satisfação no trabalho e rotatividade foi investigada por 
Hellman (1997) enquanto que Krausz, Kolowsky e Eiser (1998) pesquisaram a relação do construto com o absenteísmo e Butler e Ehrich (1999) relacionaram a satisfação no trabalho com o desempenho do colaborador na organização.

No século XXI, o construto satisfação é vislumbrado como um dos vários conceitos que trabalham com a afetividade no trabalho. Siqueira et al. (2008 apud MARTINS P., 2009, p. 44) determinam o enfoque do construto como sendo o resultado do ambiente organizacional sobre a saúde do colaborador. Para os autores, a satisfação pode ser apontada como um dos três componentes psicossociais do conceito de bem-estar no trabalho, juntamente com envolvimento com o trabalho e o comprometimento organizacional afetivo.

Siqueira e Gomide Júnior (2004) expõem que quanto à dimensionalidade, a satisfação pode ser considerada como

um conjunto de reações específicas a vários componentes do
trabalho, capazes de desencadear no indivíduo diferentes graus de
satisfação/insatisfação (visão multidimensional). Consoante essa
visão, diferentes aspectos do trabalho são considerados como fontes
de satisfação no trabalho, sendo os mais freqüentes os fatores
chefia, colegas de trabalho, o próprio trabalho, salário e
oportunidades de promoção. Enquanto chefia e colegas de trabalho
constituem-se em dimensões relativas ao ambiente social, o próprio
trabalho representa as atribuições do cargo ocupado. Salário e
oportunidades de promoção são, por sua vez, dois aspectos de
gestão de pessoas pelos quais a organização manifesta sua
retribuição ao empregado, constituindo-se em duas maneiras
possíveis do empregado observar resultados de seus investimentos
na organização e avaliar sua relação de troca com esta (SIQUEIRA;
GOMIDE JÚNIOR, 2004, p. 303).

A visão unidimensional entende a satisfação no trabalho como uma atitude geral diante do mesmo e como um todo, não julgando relevante a quantificação de reações a aspectos específicos do trabalho. Siqueira e Gomide Júnior (2004) informam que os defensores dessa perspectiva criticam a visão multidimensional justificando que aspectos particulares do trabalho são numerosos e podem variar de situação para situação, o que dificultaria a elaboração de formulações teóricas sobre o conceito. Siqueira e Gomide Júnior (2004) optaram por trabalhar com a visão multidimensional da variável satisfação no trabalho, pois acreditam que a variável é composta por um conjunto de reações específicas a cada componente, refletindo melhor o ambiente social e as relações do colaborador com ele. 
Cabe salientar que, no presente estudo, concebeu-se o construto de satisfação no trabalho como o atributo afetivo relativo ao grau de contentamento do colaborador frente ao seu trabalho, sendo, portanto, uma variável atitudinal com enfoque pós-cognitivo conforme Siqueira (1995), evidenciando assim, o caráter multidimensional escolhido. A partir de uma escala multifatorial validada por Siqueira (1995) em sua versão reduzida, analisaram-se os cinco fatores de satisfação no trabalho, quais sejam, satisfação com os colegas, satisfação com o salário, satisfação com a chefia, satisfação com a natureza do trabalho e por fim, satisfação com as promoções.

\subsubsection{Produção nacional}

Sant'anna, Moraes e Kilimnik (2005) relataram os procedimentos e resultados de validação de escalas. Essas escalas se destinavam à mensuração dos seguintes construtos: competências individuais requeridas, modernidade organizacional e satisfação no trabalho. Diagnosticaram os construtos junto a uma amostra de 654 profissionais da área da Administração. Os autores destacaram como resultado a validação das escalas propostas, assim como a percepção dos profissionais alvo do estudo quanto ao elevado grau de demanda pelo conjunto das competências investigadas, graus moderados de modernidade organizacional e satisfação no trabalho. Cabe salientar que as competências mais demandadas são as ligadas a qualidades pessoais e relacionais. Sobre a análise de modernidade organizacional, constatou-se que apesar do estímulo das organizações ao estabelecimento de climas internos mais favoráveis aos processos de aprendizagem contínuos, ao trabalho em equipe e às iniciativas de ação e decisão, existe ainda a predominância de um caráter organizacional ainda autoritário, hierarquizado e centralizado. No que tange à satisfação no trabalho, constataram baixos escores atribuídos a fatores associados à qualidade das gerências e a fatores organizacionais.

Puente-Palacios e Borges-Andrade (2005) estudaram a pertinência do efeito da interdependência de resultados do desempenho das equipes de trabalho, a partir de um modelo multinível. Investigaram, também, o efeito da interdependência de tarefas, de resultados e crenças na efetividade das equipes. Os autores 
estabeleceram as variáveis "interdependência dos resultados" e "crença na efetividade das equipes de trabalho" como características dos indivíduos enquanto a variável "interdependência de tarefas" como características de grupos. Consideraram como indicador da efetividade, a satisfação dos membros. Os resultados evidenciaram a adequação do modelo proposto, porque permitiu compreender as diferenças entre indivíduos e equipes. Observaram que existe relação direta entre interdependência de resultados e satisfação. A interdependência de tarefas modificou, em alguns casos, essa relação. Identificaram maior satisfação de indivíduos que relataram depender dos seus colegas para atingir seus resultados. A inserção das três variáveis no modelo multinível explicou diferenças entre indivíduos e equipes no que se refere à satisfação. Pode-se concluir, segundo os autores, que a satisfação não é explicada somente a partir de uma perspectiva (individual ou coletiva), mas também pela exploração do efeito conjunto de variáveis.

Campos e Malik (2008) realizaram uma pesquisa, no município de São Paulo, no afã de verificar a existência de correlação entre satisfação no trabalho dos médicos do programa e a rotatividade desses profissionais, confirmando a hipótese da existência de correlação negativa. O prestígio da instituição parceira do município na implantação do Programa de Saúde da Família figurou como o fator mais importante na determinação da rotatividade dos médicos. Outros fatores de satisfação no trabalho que apresentaram correlação com a rotatividade foram: capacitação, distância das unidades de saúde e disponibilidade de materiais e equipamentos para realização das atividades profissionais. Os indicadores de satisfação no trabalho que alcançaram níveis de excelência foram os indicadores de trabalho em equipe.

Bernstorff (2007a) investigou a satisfação profissional e o estresse ocupacional no contexto de uma instituição bancária. O estudo teve como objetivo correlacionar dados secundários oriundos de uma pesquisa institucional sobre satisfação profissional e informações sócio-demográficas e ocupacionais com dados do exame de saúde ocupacional dos trabalhadores de um banco brasileiro, avaliando se os aspectos da satisfação somados às características individuais e organizacionais afetariam significativamente a saúde mental avaliada a partir do estresse ocupacional dos colaboradores. O resultado apontou que o sentimento de trabalho em excesso manifestado pela intensificação do trabalho, satisfação profissional e saúde física são os principais influenciadores do estresse ocupacional 
somados ao esforço muscular e jornada de trabalho. Já a saúde mental foi influenciada por características individuais tais como gênero, tempo de empresa e sedentarismo. O estresse foi marcado pelo fato de o colaborador pertencer aos maiores níveis hierárquicos e nos hábitos de vida como não praticar exercícios físicos ou relaxamento. Concluiu também que todas as categorias da satisfação afetam o estresse em maior ou menor significância na ordem decrescente de influências diretas, a saber: satisfação com o ambiente social, com o conteúdo do trabalho, com o salário no emprego, com o aprendizado e com as condições. Por fim, salienta a importância da gestão da saúde psíquica e mental para o bem dos colaboradores e da organização, através da participação de todos os envolvidos.

Bernstorff (2007b) prosseguiu sua pesquisa na mesma instituição bancária, no entanto, teve como objetivo a análise de dados secundários de uma pesquisa institucional sobre satisfação profissional e a medição tanto em volume quanto em sentido da influência das características sócio-demográficas e ocupacionais de diferentes categorias de satisfação com e no trabalho. Identificou cinco categorias da satisfação, quais sejam: com o conteúdo do trabalho, com o salário, com o ambiente social, com as condições e com o aprendizado. O resultado da pesquisa concluiu que os fatores que mais afetam positivamente cada tipo de satisfação encontrada são todas as categorias, excetuando-se a satisfação com o salário que afeta negativamente a satisfação com o ambiente social e vice-versa, portanto, nos melhores ambientes sociais há mais insatisfeitos com seus salários. O excesso de trabalho foi identificado como um fator que influencia negativamente os tipos de satisfação, exceto a satisfação com o conteúdo. A conclusão aponta para a necessidade de adaptação na pesquisa institucional para enriquecê-la, agregando outras categorias como a satisfação com a segurança no emprego e as formas de gestão, bem como reformulando questões sobre ascensão profissional e a circulação da informação.

Bernstorff e Dal Rosso (2008) pesquisaram as correlações entre satisfação profissional, avaliação de desempenho por competência individual, exame de saúde ocupacional e as estratégias de resistência identificadas pelas formas de absenteísmo no trabalho. A competência individual foi avaliada em uma perspectiva de 360 graus, envolvendo superiores hierárquicos, pares, subordinados, além do próprio trabalhador. A saúde ocupacional foi averiguada pelo estresse emocional e sintomas de distúrbios osteomusculares relacionados ao trabalho. O absenteísmo do 
colaborador foi medido pela ausência de licença-saúde inferior ou igual a quinze dias. Concluíram que o estresse e os distúrbios osteomusculares relacionados ao trabalho, juntamente com a insatisfação profissional ocasiona uma resistência individual ao trabalho por meio da licença-saúde de curta duração atribuída ao desgaste e ao limite de tolerância frente às condições e à organização do trabalho. Aspectos da satisfação profissional, da competência individual e da saúde ocupacional, somados às determinadas características sócio-demográficas e ocupacionais, afetam significativamente o absenteísmo.

Cunico e Zampier (2008) realizaram uma pesquisa sobre satisfação no trabalho em uma rede de lojas do comércio varejista. O objetivo era reduzir a rotatividade através de informações importantes a serem utilizadas pelo departamento de recursos humanos no momento da contratação. A pesquisa foi realizada para identificar a predição da satisfação no trabalho por meio de técnicas de Data Mining (mineração de dados). Essa técnica foi utilizada para descobrir padrões de comportamento, atitudes e características dentro do grupo de empregados de lojas de supermercado de uma rede. Esses padrões evidenciariam a satisfação e insatisfação dos colaboradores. Os autores selecionaram três técnicas: redes neurais, análise discriminante de Fisher e regressão logística. A técnica de regressão logística mostrou-se a mais indicada para o objetivo proposto, podendo ainda, os resultados servirem como apoio para a melhoria das futuras contratações. Os autores alertam que o uso de técnicas de Data Mining não substitui o recrutamento e a seleção realizados, no entanto aquele proporciona uma escolha com maior racionalidade. Essa escolha, mais racionalizada de novos contratados e a pesquisa e atualização do banco de dados, pode proporcionar, com o tempo, o refinamento das técnicas, reduzindo as margens de erro e ainda permitindo contratações de indivíduos com tendências à satisfação, minimizando os níveis de rotatividade.

Coelho Junior e Moura (2008) tiveram como objetivo revalidar a escala de satisfação no trabalho desenvolvida por Siqueira (1995), verificando sua generalidade e fidedignidade. Realizaram o estudo em uma Instituição de Segurança Pública do Distrito Federal. O resultado confirmou a estrutura do instrumento com cinco fatores: relacionamento com a chefia ( 5 itens, $\alpha=0,90)$, relacionamento com os colegas ( 5 itens, $\alpha=0,89$ ), políticas de remuneração (5 itens, $\alpha=0,88$ ), política de promoções (5 itens, $\alpha=0,82$ ) e, por fim, natureza da tarefa ( 4 itens, $\alpha=0,76$ ). $A$ 
partir dos resultados obtidos, confirmaram a escala como confiável e importante para medir a satisfação no trabalho.

Os oito artigos apresentados foram realizados em diversos contextos como instituições bancárias, empreendimentos comerciais, hospitais e órgãos públicos, prevalecendo, entretanto, as 7 pesquisas realizadas junto ao setor público. Os objetivos variaram de validação (1 pesquisa) e revalidação (2 pesquisas) de escalas a identificação de relação e correlação de variáveis (5 pesquisas), sendo, pois, bastante diversificados os objetivos das pesquisas. O construto satisfação no trabalho foi relacionado a diferentes variáveis, tais quais: comprometimento organizacional, estresse ocupacional, clima organizacional, desempenho, modernidade organizacional, absenteísmo e rotatividade. As pesquisas foram todas quantitativas, utilizando questionários para efetuar a coleta de dados. Não se constatou a segmentação da amostra, na maioria dos casos, os autores analisaram a amostra como um todo, incluindo os diversos estratos da pirâmide hierárquica.

A seguir, o capítulo sobre métodos e técnicas de pesquisa. 


\section{MÉTODOS E TÉCNICAS DE PESQUISA}

A pesquisa é um processo complexo que envolve a visão crítica da realidade, a observação dos fenômenos e a análise da interação dos mesmos e as suas consequências. Segundo Gil (1999, p. 42), a pesquisa é definida "como o processo que tem por finalidade descobrir respostas para problemas mediante a utilização de procedimentos científicos”. Possui, portanto, um caráter pragmático. Para Kerlinger (1980), a pesquisa é uma investigação sistemática, controlada, empírica e crítica, com proposições hipotéticas sobre as supostas relações existentes entre os fenômenos naturais.

Representando uma visão mais filosófica, Minayo (1993) considera a pesquisa um recurso essencial e básico das ciências no seu questionamento e entendimento da realidade. Em suma, pode-se concluir que

alguns entendem por pesquisa o trabalho de coletar dados,
sistematizá-los e, a partir daí, fazer uma descrição da realidade.
Outros fixam-se no patamar teórico e entendem por pesquisa o
estudo e a produção de quadros teóricos de referência, que estariam
na origem da explicação da realidade. Descrever restringe-se a
constatar o que existe. Explicar corresponde a desvendar por que
existe. Outros mais acreditam que pesquisar inclui teoria e prática,
porque compreender a realidade e nela intervir formam um todo só,
tornando-se vício oportunista ficar apenas na constatação descritiva,
ou apenas na especulação teórica (DEMO P., 1989, p. 11, grifo do
autor).

Para evitar esse vício oportunista, o exercício científico foi executado de forma criteriosa para garantir a confiabilidade dos resultados para que, estes, sejam usados por algum pesquisador como base para novas pesquisas ou quem sabe, se reverta em uma ferramenta a ser utilizada em prol de melhorias para o ambiente de trabalho e qualidade de vida dos professores da Universidade de Brasília.

\subsection{Modelo e variáveis de pesquisa}

O modelo da pesquisa é subdividido em dois submodelos conforme a Figura 1. 


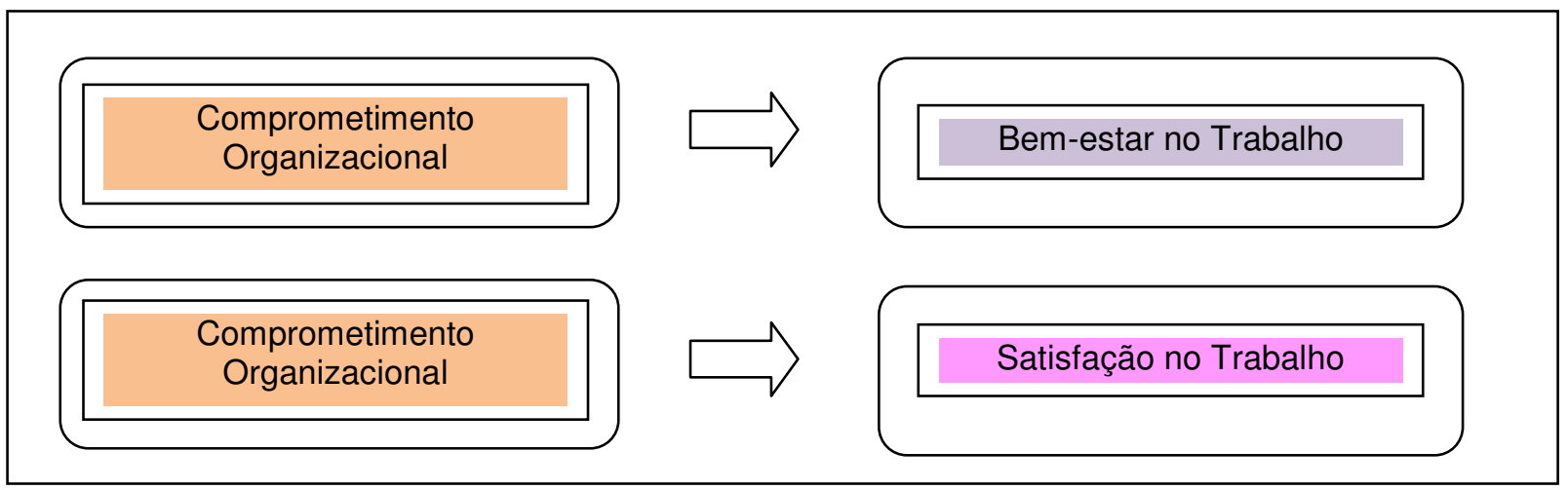

Figura 1: Submodelos de pesquisa

Fonte: Adaptado de Demo (2008, p. 112)

A variável independente e as variáveis dependentes do modelo de pesquisa estão caracterizadas no Quadro 1.

\begin{tabular}{|c|c|c|c|}
\hline Variável & Classificação & Fatores/Bases & Descrição \\
\hline \multirow{3}{*}{$\begin{array}{c}\text { Comprometimento } \\
\text { Organizacional }\end{array}$} & \multirow{3}{*}{ Independente } & Afetivo & $\begin{array}{l}\text { A identificação do colaborador com os } \\
\text { objetivos e valores da organização. }\end{array}$ \\
\hline & & Normativo & $\begin{array}{l}\text { Sentimento de obrigação de } \\
\text { permanecer na rorganização } \\
\text { desencadeado pelas pressões advindas } \\
\text { das normas e valores organizacionais. }\end{array}$ \\
\hline & & Calculativo & $\begin{array}{l}\text { Permanência motivada pela análise } \\
\text { entre os custos e benefícios associados } \\
\text { à saída da organização. }\end{array}$ \\
\hline \multirow{3}{*}{$\begin{array}{l}\text { Bem-estar no } \\
\text { Trabalho }\end{array}$} & \multirow{3}{*}{ Dependente } & Afetos Positivos & $\begin{array}{l}\text { Vivência de humores positivos acerca } \\
\text { do trabalho. }\end{array}$ \\
\hline & & Afetos Negativos & $\begin{array}{l}\text { Vivência de humores negativos acerca } \\
\text { do trabalho. }\end{array}$ \\
\hline & & Realização & $\begin{array}{l}\text { Correspondência entre os planos que a } \\
\text { pessoa fez para sua vida e as } \\
\text { atividades desenvolvidas no trabalho. }\end{array}$ \\
\hline \multirow{5}{*}{$\begin{array}{l}\text { Satisfação no } \\
\text { Trabalho }\end{array}$} & \multirow{5}{*}{ Dependente } & Chefia & $\begin{array}{l}\text { Entendimento com a chefia, maneira de } \\
\text { tratamento e capacidade profissional da } \\
\text { chefia identificada pelo colaborador. }\end{array}$ \\
\hline & & $\begin{array}{l}\text { Natureza do } \\
\text { Trabalho }\end{array}$ & $\begin{array}{l}\text { Grau de interesse pelas tarefas, } \\
\text { variedade e a capacidade de absorção } \\
\text { do colaborador. }\end{array}$ \\
\hline & & Colegas & $\begin{array}{l}\text { Sentimento de colaboração, amizade e } \\
\text { confiança entre os colaboradores. }\end{array}$ \\
\hline & & Salário & $\begin{array}{l}\text { Relação do valor recebido com a } \\
\text { quantidade de trabalho, capacidade } \\
\text { profissional e esforço dispensado pelo } \\
\text { colaborador. }\end{array}$ \\
\hline & & Promoções & $\begin{array}{l}\text { Quantidade, maneira de realização e } \\
\text { oportunidades. }\end{array}$ \\
\hline
\end{tabular}

Quadro 1: Variáveis da pesquisa

Fonte: Adaptado de Demo (2008, p. 113) 


\subsection{Tipo e descrição geral da pesquisa}

Com base na afirmação de Vergara (2006) de que a pesquisa explicativa tem como objetivo primordial esclarecer que fatores e de que forma estes contribuem para a ocorrência de um determinado fenômeno, adotou-se neste estudo, a pesquisa do tipo explicativa.

A pesquisa tem natureza quantitativa, "objetiva por natureza e focada na mensuração dos fenômenos" (COLLIS; HUSSEY, 2005, p. 26). Segundo Marconi e Lakatos (2008), as pesquisas podem sofrer limitação no que tange ao aspecto da extensão e outros fatores. Há que considerar um aspecto significativo que é a confiabilidade dos dados fornecidos pelos entrevistados. Nesse sentido, o instrumento de aplicação não possui questões de identificação dos respondentes.

O estudo possui caráter transversal, tendo em vista que as informações foram coletadas em um único momento da realidade (DRENTH, 1984 apud DEMO, 2008, p. 115).

\subsection{Caracterização da Universidade de Brasília}

A Universidade de Brasília (UnB) foi inaugurada em 21 de abril de 1962. O antropólogo Darcy Ribeiro foi o fundador e o primeiro reitor da UnB. A UnB foi a primeira universidade brasileira a ser dividida em institutos centrais e faculdades.

A UnB é considerada uma das mais importantes instituições de ensino superior do Brasil. Em 2008, ocupou a décima posição no ranking das melhores universidades do país. Esse ranking é feito a partir do novo indicador criado pelo Ministério da Educação (MEC), para avaliar a qualidade das instituições de ensino superior no Brasil, o Índice Geral de Cursos (IGC). O índice é divulgado em valores contínuos variando de 0 a 500 pontos e também, em faixas, de 1 a 5. Em 2008, a universidade que alcançou a maior pontuação foi a Federal de São Paulo (Unifesp) com 439 pontos e faixa 5 . A UnB, neste mesmo ranking ficou em décimo lugar com 384 pontos e faixa 4 .

O campus principal, Darcy Ribeiro, está localizado na área central da capital do país. A UnB é formada por 5 decanatos, 25 institutos e faculdades, 47 
departamentos, 28 mil estudantes, distribuídos em 72 cursos de graduação, sendo 16 noturnos e dois à distância, divididos em quatro campi: Plano Piloto, Planaltina, Ceilândia e Gama.

A UnB propicia o ensino, a pesquisa e a extensão de forma integrada, enriquecendo o processo de formação dos estudantes e a produção do conhecimento.

Atualmente, conta com mais de 1400 professores e 2230 servidores.
A UnB oferece 72 cursos de graduação, 64 de mestrado, 45 de
doutorado e dezenas de especializações. Os órgãos
complementares auxiliam os alunos no desenvolvimento de trabalhos
de ensino, pesquisa e extensão. Fazem parte dos órgãos
complementares o Hospital Universitário de Brasília (HUB), a
Biblioteca Central (BCE), a Fazenda Água Limpa, o Centro de
Informática, a UnB TV e a Editora UnB (UNIVERSIDADE..., 2009).

Outra inovação ocorreu em março de 1989 quando foi criado o primeiro curso noturno na UnB, o curso de Administração. Essa mudança respondeu à necessidade de incluir um novo perfil de estudantes universitários, os que trabalhavam durante o dia e que até então só contavam com as faculdades particulares. Durante a década de 1990 foram criados mais treze cursos noturnos.

O campus Darcy Ribeiro oferece uma infra-estrutura condizente com 0 tamanho do mesmo. Professores, alunos e servidores dispõem de agências bancárias, agência dos Correios, posto de gasolina, lojas de conveniência, barbearia, sapataria, papelarias, fotocopiadoras, livrarias, restaurantes e lanchonetes.

Os professores da UnB têm seu plano de carreira baseado no Decreto $\mathrm{n}^{\circ}$ 94.664, de 23 de julho de 1987 e na Medida Provisória $n^{\circ}$ 295, de 29 de maio de 2006. Esse plano de carreira dos docentes compreende cinco classes: professor auxiliar, professor assistente, professor adjunto, professor associado e professor titular. Cada classe possui quatro níveis, exceto a classe de professor titular, que possui só um nível.

Para o ingresso na carreira de professor auxiliar, exige-se diploma de graduação em curso superior, enquanto que para professor assistente cobra-se o grau de mestre. O professor adjunto deve apresentar título de doutor ou de livredocência e por fim, a carreira de professor titular é restrita a portadores do título de doutor ou de livre-docência, professores adjuntos ou pessoas de notório saber. $\mathrm{O}$ 
docente pode progredir a cada dois anos por meio de avaliação de desempenho funcional e da aquisição de novos títulos, como o de mestre e o de doutor.

\subsection{População e amostra}

O universo ou população "depende do assunto a ser investigado" (MARCONI; LAKATOS, 2008, p. 27). Assim, escolheu-se como universo da presente pesquisa o conjunto de professores que lecionam pelo menos alguma matéria de Administração na Universidade de Brasília.

A partir da análise das grades horárias disponíveis no sítio da UnB (www.unb.br), apurou-se que no segundo semestre de 2009, no Campus Darcy Ribeiro, a instituição contava com uma população de 104 professores responsáveis por mais de 66 disciplinas de Administração, mas alocados em diferentes departamentos. Cabe lembrar que um mesmo professor pode pertencer a mais de um departamento como é o caso de alguns que além de lecionarem para a graduação, também ministram aulas para o programa de pós-graduação. Essa apuração foi realizada no dia 24 de agosto de 2009, portanto, os números podem sofrer variação devido à entrada e saída de professores ao longo do semestre letivo.

Dos 104 professores, 82 são da Faculdade de Economia, Administração, Contabilidade e Ciência da Informação e Documentação (FACE). Da FACE, há 62 professores do Departamento de Administração (ADM), 19 do Programa de Pósgraduação em Administração (PPGA) e 1 do Departamento de Ciências Contábeis e Atuariais (CCA). A Faculdade de Ciências da Saúde (FS) conta com 5 professores. Desses, 2 são do Departamento de Saúde Coletiva (DSC), 2 do Departamento de Enfermagem (ENF) e 1 professor do Departamento de Nutrição (NUT). Do Instituto de Psicologia (IP), mais especificamente do Departamento de Psicologia Social e do Trabalho (PST), somam-se 4 professores. A Faculdade de Tecnologia (FT) possui 4 professores do Departamento de Engenharia Mecânica (ENM). O Instituto de Ciências Sociais (ICS) conta com 2 professores pertencentes ao Departamento de Sociologia (SOL). Assim como a Faculdade de Agronomia e Medicina Veterinária (FAV), que conta também com 2 professores. Similar também a Faculdade de Educação (FE), que conta com 2 professores do Departamento de Planejamento e 
Administração (PAD). O Instituto de Ciências Exatas (IE) conta com 1 professor do Departamento de Ciência da Computação (CIC). Semelhante a Faculdade de Comunicação (FAC), que possui 1 professor do Departamento de Audiovisuais e Publicidade (DAP) e por fim, a Faculdade de Educação Física (FEF) que conta com 1 professor na população, contabilizando, finalmente, os 104 professores distribuídos conforme a Tabela 1.

Tabela 1: Distribuição da população por Faculdade/Instituto da UnB

\begin{tabular}{ccc}
\hline Faculdade/Instituto & Quantidade absoluta & $\begin{array}{c}\text { Quantidade percentual } \\
\text { (aproximadamente) }\end{array}$ \\
\hline FACE & 82 & 78,8 \\
\hline FS & 5 & 4,8 \\
\hline IP & 4 & 3,9 \\
\hline FT & 4 & 3,9 \\
\hline ICS & 2 & 1,9 \\
\hline FAV & 2 & 1,9 \\
\hline FE & 2 & 1,9 \\
\hline Outras com apenas 1 professor & 3 & $\mathbf{1 0 0 \%}$ \\
\hline TOTAL & $\mathbf{1 0 4}$ &
\end{tabular}

Fonte: Elaborado pela autora.

Sabendo que a maioria dos professores de administração encontra-se na FACE é interessante conhecer sua lotação, conforme se observa na Tabela 2.

Tabela 2: Distribuição dos professores de Administração da FACE

\begin{tabular}{cccc} 
Departamentos da FACE & $\begin{array}{c}\text { Quantidade } \\
\text { absoluta }\end{array}$ & $\begin{array}{c}\text { Quantidade percentual } \\
\text { dentro da FACE } \\
\text { (aproximadamente) }\end{array}$ & $\begin{array}{c}\text { Quantidade percentual } \\
\text { total } \\
\text { (aproximadamente) }\end{array}$ \\
\hline $\begin{array}{c}\text { Departamento de } \\
\text { Administração (ADM) }\end{array}$ & 62 & 75,5 & 59,6 \\
\hline $\begin{array}{c}\text { Programa de Pós- } \\
\text { graduação }\end{array}$ & 19 & 23,3 & 18,3 \\
em Administração (PPGA) & 1 & 1,2 & 0,9 \\
\hline $\begin{array}{c}\text { Departamento de Ciências } \\
\text { Contábeis e Atuariais } \\
\text { (CCA) }\end{array}$ & 1 & $\mathbf{1 0 0 \%}$ & $\mathbf{7 8 , 8} \%$ \\
\hline TOTAL & $\mathbf{8 2}$ & &
\end{tabular}

Fonte: Elaborado pela autora.

É mister salientar que existem basicamente três tipos de vínculos da UnB e seus professores, a saber: efetivos, substitutos e voluntários. Ressalta-se que para atender critérios de natureza estatística, a pesquisa contou com a participação das três categorias sob pena de não obter uma amostra mínima recomendada.

A amostra utilizada foi do tipo não-probabilística por conveniência. O cálculo para designar a quantidade mínima da amostra foi assim considerado: 
[...] calcula-se o tamanho da amostra para procedimentos estatísticos como correlações e regressões múltiplas com mais de uma variável independente e uma variável dependente através da regra $\mathrm{N}=50+8 \mathrm{~m}$, onde $\mathrm{N}$ é o tamanho da amostra e $\mathrm{m}$ o número de variáveis independentes (VIs) do modelo (TABACHNICK; FIDELL, 2001 apud DEMO, 2008, p. 115).

No modelo desta pesquisa, elegeu-se uma variável independente (comprometimento organizacional) com três fatores (afetivo, calculativo e normativo), resultando em uma amostra mínima recomendada de 74 participantes.

Deve-se avaliar, ainda, a amostra mínima para obter poder estatístico. Segundo Cohen (1992), a análise do poder estatístico explora as relações entre as 3 variáveis envolvidas em inferência estatística, a saber, tamanho da amostra $(\mathrm{N})$, critério de significância ( $\alpha$ ), efeito do tamanho da população (ES) e o poder estatístico. Observando-se a tabela desenvolvida pelo autor, com $\alpha=0,05$, ES médio, poder estatístico de 0,80 (recomendados em estudos comportamentais) e quantidade de variável independente igual a um (para a presente pesquisa), obtevese uma amostra mínima recomendada para o uso da regressão linear de, aproximadamente, 76 participantes.

Sendo assim, aplicaram-se mais questionários do que o número mínimo sugerido para que após a limpeza e o tratamento dos dados, a amostra final contasse com o número recomendado de participantes. Tendo em vista o universo de 104 professores, a coleta de 76 questionários válidos corresponde a aproximadamente $73 \%$ do total.

\subsection{Caracterização dos instrumentos de pesquisa}

Para compor a versão final do instrumento de aplicação (anexo A), foram utilizados cinco instrumentos (tipo questionários) de mensuração, quais sejam: escalas de comprometimento organizacional - subdividindo-se em três componentes: afetivo (ECOA), calculativo (ECOC) e normativo (ECON), escala de bem-estar no trabalho (EBET) e escala de satisfação no trabalho (EST). 


\subsubsection{Escala de comprometimento organizacional}

A mensuração de comprometimento organizacional nas bases afetiva e calculativa foi validada por Siqueira (1995) e na base normativa, pela mesma autora em data posterior, Siqueira (2000) compreendendo três instrumentos de pesquisa, quais sejam: Escala de Comprometimento Organizacional Afetivo (ECOA), Escala de Comprometimento Organizacional Calculativo (ECOC) e Escala de Comprometimento Organizacional Normativo (ECON). A base afetiva aparece com cinco itens, enquanto que a calculativa conta com quinze itens e por fim, a base normativa possui sete itens, perfazendo um total de vinte e sete itens. Os índices de confiabilidade variam de 0,86 a 0,93. Constata-se que os instrumentos atingiram bons parâmetros psicométricos, sendo válidos para o uso em pesquisas científicas.

O total da variância explicada do fator afetivo corresponde a 68,20\%, o fator calculativo apresentou a variância explicada de 56,80\% enquanto que o fator normativo teve sua variância explicada na ordem de 50,87\%. Para os itens da base afetiva, foi utilizada uma escala no modelo Likert de cinco pontos, variando de 1 (nada) a 5 (extremamente). Na sequência, foram inseridos os itens correspondentes às bases calculativa e normativa onde os cinco pontos do modelo Likert variavam de 1 (discordo totalmente) a 5 (concordo totalmente), conforme explicitado na Tabela 3.

Tabela 3: Composição dos fatores da ECO

\begin{tabular}{ccccc} 
Fatores & Itens & Total & $\begin{array}{c}\text { Índice de } \\
\text { Confiabilidade } \\
\text { (alpha de Cronbach) }\end{array}$ & $\begin{array}{c}\text { Total da } \\
\text { variância } \\
\text { explicada }\end{array}$ \\
\hline Afetivo & 31 a 35 & 5 & 0,93 & $68,20 \%$ \\
\hline Calculativo & 36 a 50 & 15 & 0,92 & $56,80 \%$ \\
\hline Normativo & 51 a 57 & 7 & 0,86 & $50,87 \%$ \\
\hline
\end{tabular}

TOTAL 27

Fonte: Adaptada de Siqueira (2008)

\subsubsection{Escala de bem-estar no trabalho}

A escala de bem-estar no trabalho foi validada por Paschoal e Tamayo (2008). A escala é dividida em três fatores, quais sejam: emoções/humores 
positivos, emoções/humores negativos e expressividade/realização no trabalho. Apresenta-se, destarte, afeto positivo com nove itens, afeto negativo com doze itens e realização com nove itens, perfazendo um total de trinta itens. "Os coeficientes de fidedignidade variaram de 0,88 a 0,93. O instrumento apresentou bons parâmetros psicométricos e tem utilidade em pesquisas científicas e em diagnóstico organizacional" (PASCHOAL; TAMAYO, 2008, p.11). Conforme Pasquali (2001), coeficientes de fidedignidade ( $\alpha$ de Cronbach) superiores a 0,75 são considerados bons para a pesquisa científica.

O total da variância explicada corresponde a 57,30\%. Para os itens de afeto (positivo e negativo), foi utilizada uma escala no modelo Likert de cinco pontos para resposta: 1 - nem um pouco, 2 - um pouco, 3 - moderadamente, 4 - bastante e 5 extremamente. Após os itens de afeto, foram inseridos os itens correspondentes à realização/expressividade, com instruções específicas e uma escala de concordância de cinco pontos: 1 - discordo totalmente, 2 - discordo, 3 - concordo em parte, 4 - concordo e 5 - concordo totalmente, conforme demonstrado na Tabela 4.

Tabela 4: Composição dos fatores da EBET

\begin{tabular}{cccc} 
Fatores & Itens & Total & $\begin{array}{c}\text { Índice de Confiabilidade } \\
\text { (alpha de Cronbach) }\end{array}$ \\
\hline Afeto positivo & $1,3,4,8,11,13,17,19$ e 21 & 9 & 0,93 \\
\hline Afeto negativo & $2,5,6,7,9,10,12,14,15,16,18$ e 20 & 12 & 0,91 \\
\hline Realização & 22 a 30 & 9 & 0,88
\end{tabular}

TOTAL

Fonte: Adaptada de Paschoal e Tamayo (2008)
30
Total da variância explicada: $57,30 \%$

\subsubsection{Escala de satisfação no trabalho}

Foi utilizada a escala de satisfação no trabalho, em sua versão reduzida, construída e validada por Siqueira (1995). A escala é uma medida multidimensional para avaliar o grau de satisfação do colaborador nas cinco dimensões do construto, quais sejam: satisfação com os colegas, satisfação com o salário, satisfação com a chefia, satisfação com a natureza do trabalho e satisfação com as promoções. Cada 
dimensão conta com três itens, perfazendo um total de 15 itens. Os coeficientes de fidedignidade variaram de 0,77 a 0,90, sendo, portanto, um instrumento apto e capaz de fornecer resultados úteis e confiáveis para pesquisas científicas.

O total da variância explicada corresponde a $64,80 \%$. Utilizou-se uma escala no modelo Likert de cinco pontos, variando de 1 (discordo totalmente) a 5 (concordo totalmente), conforme Tabela 5.

Tabela 5: Composição dos fatores da EST

\begin{tabular}{cccc} 
Fatores & Itens & Total & $\begin{array}{c}\text { Índice de } \\
\text { Confiabilidade } \\
\text { (alpha de Cronbach) }\end{array}$ \\
\hline Satisfação com os colegas & 58,61 e 71 & 3 & 0,81 \\
\hline Satisfação com o salário & 60,63 e 68 & 3 & 0,90 \\
\hline Satisfação com a chefia & 67,69 e 72 & 3 & 0,89 \\
\hline $\begin{array}{c}\text { Satisfação com a natureza do } \\
\text { trabalho }\end{array}$ & 62,65 e 70 & 3 & 0,77 \\
\hline Satisfação com as promoções & 59,64 e 66 & 3 & 0,81 \\
\hline & TOTAL & $\mathbf{1 5}$ & $\begin{array}{c}\text { Total da variância } \\
\text { explicada: } \\
\mathbf{6 4 , 8 0 \%}\end{array}$
\end{tabular}

Fonte: Adaptada de Siqueira (2008).

\subsection{Procedimentos de coleta e de análise de dados}

A coleta de dados foi realizada da seguinte forma: contato pessoal ou via correio eletrônico com cada professor, informando o objetivo da pesquisa, apresentando o questionário e seus critérios para preenchimento bem como o prazo para devolução do mesmo. A coleta foi concluída em 53 dias, iniciando no dia 26.08.2009 e terminando no dia 17.10.2009. Dessa forma, entende-se que

os processos estatísticos permitem obter, de conjuntos complexos, representações simples e constatar se essas verificações simplificadas têm relações entre si. Assim o método estatístico significa redução de fenômenos sociológicos, políticos, econômicos etc a termos quantitativos e a manipulação estatística, que permite comprovar as relações dos fenômenos entre si, e obter generalizações sobre sua natureza, ocorrência ou significado (MARCONI; LAKATOS, 2004, p.93). 
As análises estatísticas foram fundamentais para a consecução dos objetivos. Inicialmente, foi feita uma análise descritiva, utilizando médias e gráficos para atender aos três objetivos específicos propostos na pesquisa, a saber, identificar o comprometimento organizacional, o bem-estar e a satisfação no trabalho dos professores. Para esta fase, foi utilizado o Excel. Em segunda instância, foram realizadas

análises exploratórias dos dados para examinar questões como multicolinearidade e singularidade, normalidade, omissão de informações e presença de outliers (valores claramente afastados dos demais valores e da média) e análises de distribuição de freqüência para constatar sua coerência (média, desvios-padrão e valores máximo e mínimo dentro do esperado). Tais análises visam adequar os dados para aproximá-los dos pressupostos das análises do modelo linear geral (DEMO, 2008, p. 116).

Por fim, foram efetuadas as análises de regressão do tipo stepwise para obter a relação entre as variáveis, o objetivo específico da pesquisa. Para simplesmente avaliar relações entre variáveis sem pretensões de identificar o poder preditivo de cada variável independente de maneira individual, pode-se usar a regressão padrão (TABACHNICK; FIDELL, 2001 apud DEMO, 2008, p. 115). Já a regressão stepwise, apesar de ser baseada em critérios puramente estatísticos, pressupõe que o pesquisador possui algum embasamento teórico, porém não muito consistente. $O$ uso desta regressão é típico de estudos explicativos onde se pretende construir modelos e investigar relações pouco conhecidas entre variáveis.

As autoras Tabachnick e Fidell (2001 apud DEMO, 2008, p. 115) também afirmam que se a pretensão do investigador é descobrir qual é a melhor combinação linear de variáveis independentes que predizem uma variável dependente em uma determinada amostra, a melhor escolha é a regressão stepwise, que também fornece as contribuições individuais dos preditores de maneira mais pura e precisa que a regressão padrão (e o objetivo desta pesquisa foi identificar melhores preditores). Deve-se considerar, ainda, que neste estudo buscou-se construir um modelo teórico de investigação que levanta hipóteses de relações entre variáveis que podem até terem sido sugeridas de maneira mais vaga na literatura, mas que ainda não possibilitam afirmações consistentes sobre a magnitude ou direção destas relações, não se caracterizando o estudo como confirmatório e sem a utilização da regressão hierárquica. 
Nestas últimas análises, foi utilizado o programa estatístico Statistical Package for the Social Sciences (SPSS), versão 13.0.

O capítulo ulterior apresentará os resultados e sua discussão. 


\section{RESULTADOS E DISCUSSÃO}

Este capítulo destina-se a apresentar os resultados produzidos pela pesquisa realizada, segundo cada objetivo proposto. Encerra-se com a síntese dos resultados obtidos.

\subsection{Limpeza e tratamento dos dados}

A quantidade de questionários devolvidos foi satisfatória, tendo em vista que foram distribuídos 104 e destes, 81 foram devolvidos. Essa quantidade representa $77,88 \%$ do universo pesquisado.

O primeiro passo foi a realização da análise de dados por meio da distribuição de frequências (média, desvio padrão, variância, mínimo e máximo), demonstrando assim, a coerência dos dados. Quanto ao tratamento dos dados, optou-se pelo tratamento listwise que exclui os questionários com dados faltantes. A partir disso, foram excluídos 4 questionários, resultando 77 questionários válidos.

$\mathrm{Na}$ sequência, procedeu-se à análise de verificação de outliers, que correspondem a valores discrepantes dos demais, os casos atípicos. Segundo as autoras Tabachnick e Fidell (2001 apud MARTINS P., 2009, p. 71), a identificação de outliers multivariados deve ser realizada através da distância Mahalanobis. Para esta pesquisa, com 3 graus de liberdade correspondendo à quantidade de fatores da variável independente do modelo e com índice de significância estatística $p<0,001$, obteve-se o qui-quadrado $X^{2}=16,266$. Assim, o resultado apontou 1 outlier multivariado. Houve, assim, a necessidade de excluir este questionário da amostra, sendo aproveitados para as análises de regressão 76 sujeitos, compondo a amostra final de $73,08 \%$ da população. Por fim, o diagnóstico de multicolinariedade foi favorável, lembrando que a regressão do tipo stepwise também neutraliza os efeitos de multicolinariedade. 


\subsection{Identificação do comprometimento organizacional}

O primeiro objetivo proposto foi identificar o comprometimento organizacional dos professores que lecionam disciplinas de Administração na Universidade de Brasília. Para tal, é apresentado o Gráfico 1, com as médias dos escores obtidos para cada base, a saber, afetiva, normativa e calculativa, em ordem decrescente de média.

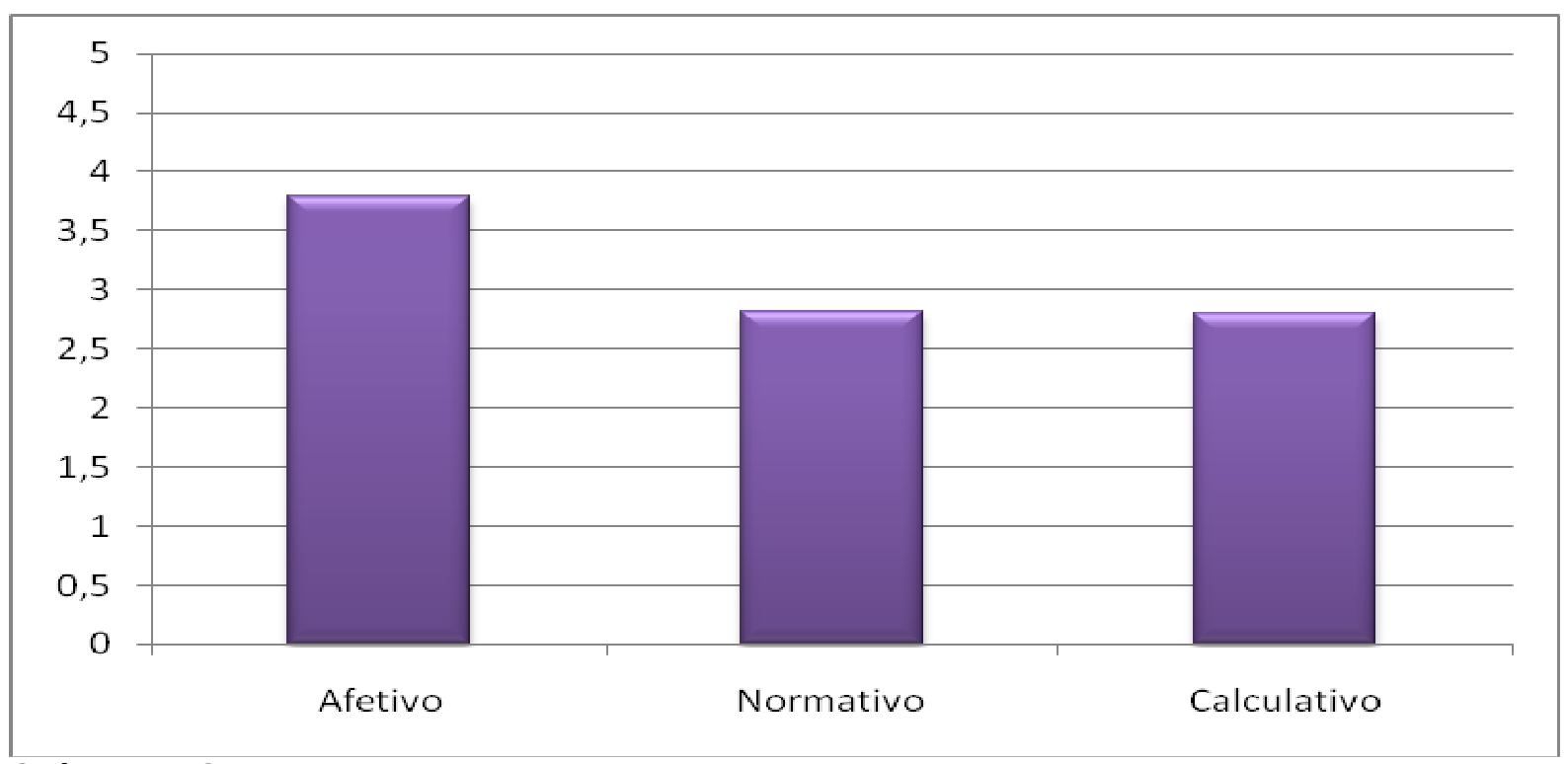

Gráfico 1: Comprometimento organizacional

Fonte: Dados primários coletados pela autora

De acordo com o gráfico, os professores são mais comprometidos afetivamente (a identificação do colaborador com os objetivos e valores da organização o fazem permanecer nela) com uma média de 3,79, ficando, na escala, próximo de "muito". Quanto às bases normativa (sentimento de obrigação de permanecer na organização desencadeado pelas pressões advindas de normas e valores organizacionais) e calculativa (permanência do colaborador na empresa motivado pela análise entre os custos e benefícios associados a sua saída), o gráfico apresenta médias bem próximas, respectivamente, 2,82 e 2,80. Considerando "3" como o ponto neutro que corresponde, no questionário, a "não concordo nem discordo" nas escalas de comprometimento organizacional calculativo e normativo, percebe-se que os professores não são comprometidos nessas bases. A partir desses resultados, pode-se inferir que os professores se mantem na UnB porque realmente gostam e acreditam na instituição e não por se sentirem obrigados 
ou atrelados apenas aos ganhos proporcionados por trabalharem na mencionada instituição. A distribuição de frequências, apresentada na Tabela 6, colabora para a melhor compreensão dos resultados.

Tabela 6: Distribuição de frequência do comprometimento organizacional

Comprometimento Média Desvio Padrão Variância Máximo Mínimo organizacional

\begin{tabular}{cccccc}
\hline Afetivo & 3,79 & 0,8239 & 0,6788 & 5 & 1,40 \\
\hline Normativo & 2,82 & 0,8286 & 0,6866 & 4,71 & 1 \\
\hline Calculativo & 2,80 & 0,7897 & 0,6237 & 4,33 & 1,33
\end{tabular}

Fonte: Dados primários coletados pela autora

\subsection{Identificação do bem-estar no trabalho}

O segundo objetivo proposto foi identificar o bem-estar dos professores que lecionam disciplinas de Administração na Universidade de Brasília. A partir disso, são apresentadas, graficamente, as médias dos escores obtidos na pesquisa. $O$ Gráfico 2 apresenta o bem-estar pesquisado quanto aos fatores "afetos positivos, afetos negativos e realização", em ordem decrescente de média.

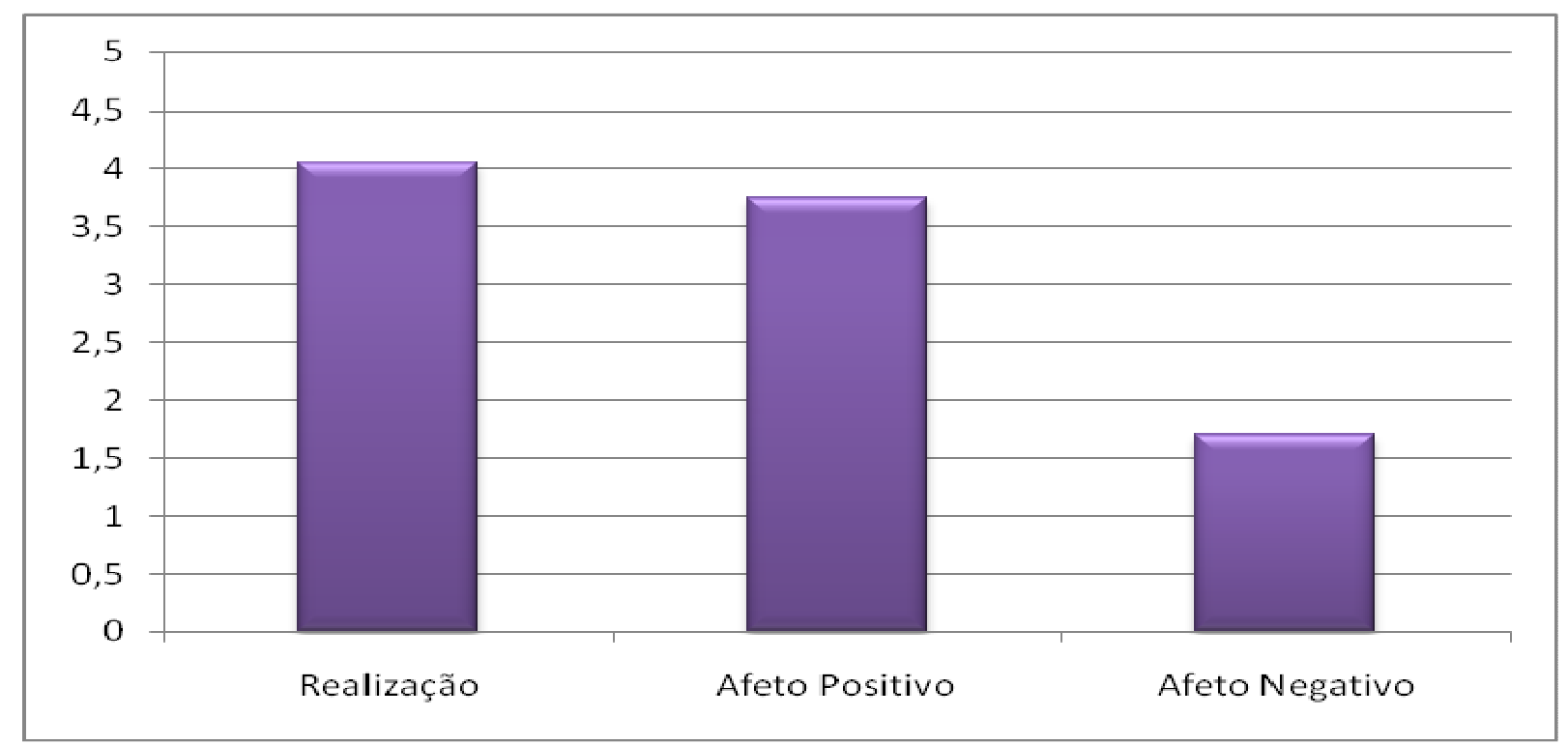

Gráfico 2: Bem-estar no trabalho

Fonte: Dados primários coletados pela autora 
Os professores de disciplinas de Administração da UnB apresentam o fator realização (correspondência entre os planos que o colaborador fez para sua vida e as atividades desenvolvidas no trabalho) como o mais expressivo da variável bemestar no trabalho, aferindo-se uma média de 4,05, correspondente no questionário a "concordo". A segunda maior média foi do fator afeto positivo (vivência de humores positivos acerca do trabalho) com 3,75 que corresponde a "concordo" e, por último, constatou-se o afeto negativo (vivência de humores negativos acerca do trabalho) com média de 1,71, significando "um pouco". Percebe-se que os professores apresentaram bons níveis de realização no trabalho e afetos positivos enquanto que os afetos negativos foram pouco representados. Pode-se afirmar que trabalhar na UnB contribui para os planos e metas que os professores traçaram para as suas vidas e, ainda, vivem experiências positivas através da percepção de humores positivos na instituição como alegria, disposição, contentamento, entusiasmo e outros estados favoráveis e pelo fato de apresentarem poucas experiências de afetos negativos como ansiedade, chateação, tensão, raiva e tédio.

A distribuição de frequências para o bem-estar no trabalho é apresentada na Tabela 7.

Tabela 7: Distribuição de frequência do bem-estar no trabalho

\begin{tabular}{cccccc} 
Bem-estar no trabalho & Média & Desvio Padrão & Variância & Máximo & Mínimo \\
\hline Realização & 4,05 & 0,6615 & 0,4377 & 5 & 2,44 \\
\hline Afeto positivo & 3,75 & 0,6974 & 0,4863 & 5 & 1,56 \\
\hline Afeto negativo & 1,71 & 0,6365 & 0,4052 & 4,33 & 1
\end{tabular}

Fonte: Dados primários coletados pela autora.

\subsection{Identificação da satisfação no trabalho}

O terceiro objetivo proposto foi identificar a satisfação no trabalho dos professores que lecionam disciplinas de Administração na Universidade de Brasília. Dessa forma, são apresentadas, graficamente, as médias dos escores obtidos na pesquisa. O Gráfico 3 apresenta, em ordem decrescente de média os fatores do construto satisfação no trabalho, a saber: satisfação com os colegas, com a natureza do trabalho, com a chefia, com promoções e com o salário. 


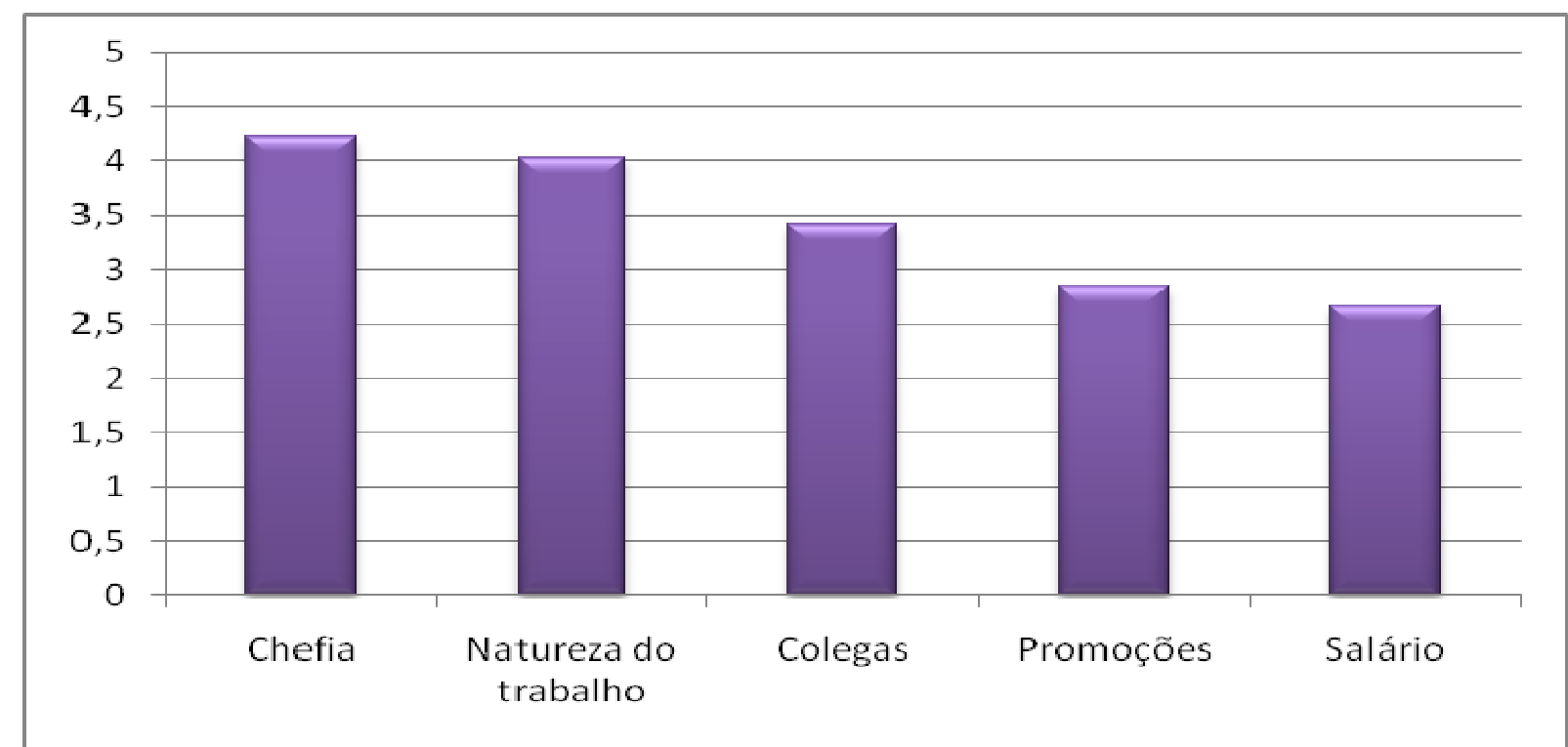

Gráfico 3: Satisfação no trabalho

Fonte: Dados primários coletados pela autora

O gráfico apresentado revela que os professores que lecionam disciplinas de Administração na UnB estão mais satisfeitos com a chefia (entendimento com a chefia, maneira de tratamento e capacidade profissional identificada pelo professor), apresentando a média de 4,23, no questionário correspondendo a "satisfeito". Em seguida, está a satisfação com a natureza do trabalho (grau de interesse pelas atividades, variedade e sua capacidade de absorção) e depois a satisfação com os colegas (sentimento de colaboração, amizade e confiança entre os professores) com as médias de 4,02 e 3,42, respectivamente, correspondendo a "satisfeito" e "pouco satisfeito" na escala.

Por último, encontram-se a satisfação com as promoções (quantidade, maneira de realização e oportunidades) com a média de 2,85 e a satisfação com o salário (relação do valor recebido com a quantidade de trabalho, capacidade profissional e esforço dispensado) com a média de 2,67, correspondendo na escala como "indiferente".

A partir dos resultados, pode-se inferir que os professores estão satisfeitos com a capacidade profissional do seu chefe, bem como com o entendimento e o relacionamento entre chefe e professor. Os professores também estão satisfeitos com a natureza do trabalho composta pelas atividades docentes, variedade do trabalho e sua capacidade de absorção. No que tange à relação com os colegas, representado pela amizade, colaboração e confiança, os professores se dizem pouco satisfeitos. Diante dessa análise, pode-se concluir que os professores estão 
praticamente indiferentes em relação ao salário, à quantidade de trabalho em relação ao quanto recebem, às promoções, à quantidade delas, à maneira como são realizadas e às oportunidades reconhecidas na Instituição. A Tabela 8 apresenta os resultados encontrados através da distribuição de frequências dos componentes da satisfação no trabalho.

Tabela 8: Distribuição de frequência da satisfação no trabalho

\begin{tabular}{cccccc}
$\begin{array}{c}\text { Satisfação } \\
\text { no trabalho }\end{array}$ & Média & Desvio Padrão & Variância & Máximo & Mínimo \\
\hline Chefia & 4,23 & 0,6648 & 0,4420 & 5 & 2,33 \\
\hline Natureza do trabalho & 4,02 & 0,6086 & 0,3704 & 5 & 2 \\
\hline Colegas & 3,42 & 0,7095 & 0,5035 & 5 & 1,33 \\
\hline Promoções & 2,85 & 0,8726 & 0,7614 & 4,67 & 1 \\
\hline Salário & 2,67 & 0,9550 & 0,9121 & 4,33 & 1
\end{tabular}

Fonte: Dados primários coletados pela autora

\subsection{Relações entre comprometimento organizacional, bem-estar no trabalho e satisfação no trabalho}

O objetivo geral proposto foi avaliar a influência do comprometimento organizacional dos professores que lecionam disciplinas de Administração na Universidade de Brasília em seu bem-estar no trabalho e na sua satisfação no trabalho, verificando os melhores preditores da satisfação no trabalho e do bemestar no trabalho a partir dos modelos propostos.

Foram, portanto, realizadas 8 regressões múltiplas, referente às 3 bases da variável bem-estar no trabalho e, as demais referentes aos 5 fatores da variável satisfação no trabalho.

Tabachnick e Fidell (2001 apud DEMO, 2008, p. 117) tecem algumas considerações sobre a qualidade do modelo de investigação adotado para a avaliação de uma pesquisa. Essa qualidade pode ser aferida através de alguns valores:

- O coeficiente de determinação, $\mathrm{R}^{2}$ apresenta a quantidade da variância da variável dependente explicada em conjunto pelas 
variáveis independentes, sendo assim, o parâmetro mais indicado para interpretar os resultados obtidos em uma regressão;

- O coeficiente de correlação padronizado, o parâmetro $\beta$, na equação de regressão múltipla, representa a magnitude e a direção do relacionamento entre cada um dos preditores e as variáveis critério;

- A significância estatística dos resultados obtidos pela análise de variância (ANOVA). O valor estatisticamente significante deve ser inferior ou igual a 0,05 ou $5 \%$, ou seja, $p<0,05$;

- O parâmetro de correlação semiparcial quadrada $\mathrm{sr}^{2}$ para avaliar a importância de cada variável independente na equação de regressão (maior poder de predição ou maior contribuição na explicação da variância total da variável dependente). O parâmetro expressa a contribuição única de cada variável independente na variância total da variável dependente, em outras palavras, indica a quantidade em que $\mathrm{R}^{2}$ é reduzido se a variável independente correspondente for retirada da equação de regressão.

\subsubsection{Regressão múltipla tendo como variável dependente a dimensão "afeto positivo" do bem-estar no trabalho}

A Tabela 9 apresenta os principais resultados da regressão múltipla, tendo como variável dependente a dimensão "afeto positivo" do bem-estar no trabalho.

Tabela 9: Preditores da dimensão "afeto positivo" do bem-estar no trabalho

\begin{tabular}{|c|c|c|c|}
\hline \multicolumn{4}{|c|}{ Variável dependente: Bem-estar afeto positivo } \\
\hline Variável & Beta $(\beta)$ & Sig. $(p<0,05)$ & $s r^{2}$ \\
\hline $\begin{array}{c}\text { Comprometimento } \\
\text { organizacional } \\
\text { afetivo }\end{array}$ & 0,531 & 0,00 & 0,281 \\
\hline \multicolumn{4}{|c|}{$\begin{array}{l}\text { Coeficiente de Regressão } \\
\qquad R=0,531\end{array}$} \\
\hline \multicolumn{4}{|c|}{$\begin{array}{c}\text { Variância Explicada } \\
\mathrm{R}^{2}=0,281 \text { ou } 28,1 \% ; R^{2} \text { ajustado }=0,272 \text { ou } 27,2 \%\end{array}$} \\
\hline \multicolumn{4}{|c|}{$\begin{array}{c}\text { Teste Estatístico } \\
\mathrm{F}(1 / 76)=28,992 ; \mathrm{p}=0,000\end{array}$} \\
\hline
\end{tabular}

Fonte: Dados primários coletados pela autora. Adaptado de Demo (2008, p. 130) 
Os resultados da análise de regressão apontaram como preditor da dimensão "afeto positivo" do bem-estar no trabalho, o comprometimento organizacional afetivo. A sua contribuição na explicação da variável dependente foi de $28,1 \%$. O comprometimento organizacional afetivo se relaciona positivamente $(\beta>0)$ com a dimensão "afeto positivo" do bem-estar no trabalho, significando que quanto mais o professor possua compromisso afetivo, maior a percepção de humores positivos no ambiente de trabalho. Em suma, o professor que mantém o vínculo com a Instituição por, principalmente, gostar dela, tenderá a ostentar maiores níveis de humores positivos ele tenderá a ostentar, como por exemplo, alegria, contentamento, animação, entusiasmo e empolgação. De acordo com o modelo proposto, o comprometimento organizacional afetivo foi o único preditor da dimensão "afeto positivo" do bem-estar no trabalho no modelo proposto.

\subsubsection{Regressão múltipla tendo como variável dependente a dimensão "afeto negativo" do bem-estar no trabalho}

A Tabela 10 apresenta os principais resultados da regressão múltipla, tendo como variável dependente a dimensão "afeto negativo" do bem-estar no trabalho.

Tabela 10: Preditores da dimensão "afeto negativo" do bem-estar no trabalho

\begin{tabular}{|c|c|c|c|}
\hline \multicolumn{4}{|c|}{ Variável dependente: Bem-estar afeto negativo } \\
\hline Variável & Beta $(\beta)$ & Sig. $(p<0,05)$ & $s r^{2}$ \\
\hline $\begin{array}{c}\text { Comprometimento } \\
\text { organizacional } \\
\text { afetivo }\end{array}$ & $-0,246$ & 0,03 & 0,061 \\
\hline \multicolumn{4}{|c|}{$\begin{array}{c}\text { Coeficiente de Regressão } \\
R=0,246\end{array}$} \\
\hline \multicolumn{4}{|c|}{$\begin{array}{c}\text { Variância Explicada } \\
\mathrm{R}^{2}=0,061 \text { ou } 6,1 \% ; R^{2} \text { ajustado }=0,048 \text { ou } 4,8 \%\end{array}$} \\
\hline & $\mathrm{F}(1 / 76$ & $\begin{array}{l}\text { ístico } \\
; p<0,032\end{array}$ & \\
\hline
\end{tabular}

Fonte: Dados primários coletados pela autora. Adaptado de Demo (2008, p. 130)

Os resultados da análise de regressão apontaram como preditor da dimensão "afeto negativo" do bem-estar no trabalho, o comprometimento organizacional afetivo. A sua contribuição na explicação da variável dependente foi de $6,1 \%$. 0 comprometimento organizacional afetivo se relaciona negativamente $(\beta<0)$ com 0 
bem-estar afeto negativo no trabalho. Isso significa que o professor que está comprometido afetivamente com a UnB tende a apresentar menos humores negativos no trabalho como, por exemplo, preocupação, irritação, depressão, tédio, frustração, raiva e tensão. O comprometimento organizacional afetivo foi o único preditor da dimensão afeto negativo do bem-estar no trabalho, no modelo proposto.

\subsubsection{Regressão múltipla tendo como variável dependente a dimensão "realização" do bem-estar no trabalho}

A Tabela 11 apresenta os principais resultados da regressão múltipla, tendo como variável dependente a dimensão "realização" do bem-estar no trabalho.

Tabela 11: Preditores da dimensão "realização" do bem-estar no trabalho

\begin{tabular}{cccc} 
& \multicolumn{4}{c}{ Variável dependente: Bem-estar realização } & \\
\hline Variável & $\operatorname{Beta}(\beta)$ & Sig. $(p<0,05)$ & $\mathrm{sr}^{2}$ \\
\hline $\begin{array}{c}\text { Comprometimento } \\
\text { organizacional } \\
\text { afetivo }\end{array}$ & 0,438 & 0,00 & 0,233 \\
\hline
\end{tabular}

\begin{tabular}{c} 
Coeficiente de Regressão \\
$R=0,483$ \\
Variância Explicada \\
$R^{2}=0,233$ ou $23,3 \% ; R^{2}$ ajustado $=0,223$ ou $22,3 \%$ \\
Teste Estatístico \\
$F(1 / 76)=22,534 ; p=0,000$ \\
\hline
\end{tabular}

Fonte: Dados primários coletados pela autora. Adaptado de Demo (2008, p. 130)

Os resultados da análise de regressão apontaram como preditor da dimensão "realização" do bem-estar no trabalho, o comprometimento organizacional afetivo. A sua contribuição na explicação da variável dependente foi de $23,3 \%$. O comprometimento organizacional afetivo se relaciona positivamente $(\beta>0)$ com a dimensão "realização" do bem-estar no trabalho. Em outras palavras, o professor que se mantém na instituição porque gosta dela, tende a apresentar maior nível de realização, ou seja, cumpre as metas que estabeleceu para sua vida em relação ao trabalho. O comprometimento organizacional afetivo foi o único preditor da dimensão "realização" do bem-estar no trabalho no modelo proposto. 


\subsubsection{Regressão múltipla tendo como variável dependente a satisfação no trabalho com o salário}

A Tabela 12 apresenta os principais resultados da regressão múltipla, tendo como variável dependente a satisfação com salário.

Tabela 12: Preditores da satisfação com o salário

\begin{tabular}{|c|c|c|c|}
\hline \multicolumn{4}{|c|}{ Variável dependente: Satisfação com salário } \\
\hline Variável & Beta $(\beta)$ & Sig. $(p<0,05)$ & $s r^{2}$ \\
\hline $\begin{array}{l}\text { Comprometimento } \\
\text { organizacional } \\
\text { normativo }\end{array}$ & 0,263 & 0,00 & 0,161 \\
\hline $\begin{array}{l}\text { Comprometimento } \\
\text { organizacional } \\
\text { calculativo }\end{array}$ & 0,261 & 0,03 & 0,049 \\
\hline \multicolumn{4}{|c|}{$\begin{array}{l}\text { Coeficiente de Regressão } \\
\qquad R=0,458\end{array}$} \\
\hline \multicolumn{4}{|c|}{$\begin{array}{c}\text { Variância Explicada } \\
R^{2}=0,210 \text { ou } 21 \% ; R^{2} \text { ajustado }=0,188 \text { ou } 18,8 \%\end{array}$} \\
\hline & $\begin{array}{r}\mathrm{Te} \\
\mathrm{F}(2 / 76)\end{array}$ & $\begin{array}{l}\text { ístico } \\
; p<0,037\end{array}$ & \\
\hline
\end{tabular}

Fonte: Dados primários coletados pela autora. Adaptado de Demo (2008, p. 130)

Os resultados da análise de regressão apontaram como preditores da variável satisfação com o salário, o comprometimento organizacional nas bases normativa e calculativa. As suas contribuições para a explicação da variável dependente foram de $21 \%$, sendo $16,1 \%$ do comprometimento organizacional normativo e $4,9 \%$ do comprometimento organizacional calculativo. Os comprometimentos organizacionais normativo e calculativo se relacionam positivamente $(\beta>0)$ com a satisfação com o salário, significando que os professores que se mantém na instituição por sentimento de obrigação (normativo) ou por vislumbrar uma vantagem em relação a outras oportunidades (calculativo), mostraram-se mais satisfeitos com o salário e acreditam que há uma compatibilidade entre os esforços empregados e a remuneração recebida. Destacou-se o comprometimento organizacional normativo como o melhor preditor da satisfação com o salário, de acordo com o modelo proposto. 


\subsubsection{Regressão múltipla tendo como variável dependente a satisfação no trabalho com os colegas}

A Tabela 13 apresenta os principais resultados da regressão múltipla, tendo como variável dependente a satisfação com os colegas.

Tabela 13: Preditores da satisfação com os colegas

\begin{tabular}{|c|c|c|c|}
\hline \multicolumn{4}{|c|}{ Variável dependente: Satisfação com os colegas } \\
\hline Variável & Beta $(\beta)$ & Sig. $(p<0,05)$ & $s r^{2}$ \\
\hline $\begin{array}{l}\text { Comprometimento } \\
\text { organizacional } \\
\text { afetivo }\end{array}$ & 0,386 & 0,00 & 0,149 \\
\hline \multicolumn{4}{|c|}{$\begin{array}{l}\text { Coeficiente de Regressão } \\
\qquad R=0,386\end{array}$} \\
\hline \multicolumn{4}{|c|}{$\begin{array}{c}\text { Variância Explicada } \\
\mathrm{R}^{2}=0,149 \text { ou } 14,9 \% ; R^{2} \text { ajustado }=0,137 \text { ou } 13,7 \% \\
\end{array}$} \\
\hline \multicolumn{4}{|c|}{$\begin{array}{c}\text { Teste Estatístico } \\
F(1 / 76)=12,945 ; p<0,001\end{array}$} \\
\hline
\end{tabular}

Fonte: Dados primários coletados pela autora. Adaptado de Demo (2008, p. 130)

Os resultados da análise de regressão apontaram como preditor da variável satisfação com os colegas, o comprometimento organizacional afetivo. A sua contribuição na explicação da variável dependente foi de 14,9\%. O comprometimento organizacional afetivo se relaciona positivamente $(\beta>0)$ com a satisfação com os colegas, significando que quando o professor permanece na instituição por realmente gostar dela, tende a ser mais satisfeito com seus colegas, mantendo um ambiente de amizade e colaboração. O comprometimento organizacional afetivo foi o único preditor da satisfação com os colegas, segundo o modelo proposto.

\subsubsection{Regressão múltipla tendo como variável dependente a satisfação no trabalho com a chefia}

A Tabela 14 apresenta os principais resultados da regressão múltipla, tendo como variável dependente a satisfação com a chefia. 
Tabela 14: Preditores da satisfação com a chefia

\begin{tabular}{|c|c|c|c|}
\hline \multicolumn{4}{|c|}{ Variável dependente: Satisfação com a chefia } \\
\hline Variável & Beta $(\beta)$ & Sig. $(p<0,05)$ & $s r^{2}$ \\
\hline $\begin{array}{c}\text { Comprometimento } \\
\text { organizacional } \\
\text { afetivo }\end{array}$ & 0,431 & 0,00 & 0,233 \\
\hline $\begin{array}{l}\text { Comprometimento } \\
\text { organizacional } \\
\text { calculativo }\end{array}$ & 0,240 & 0,00 & 0,055 \\
\hline \multicolumn{4}{|c|}{$\begin{array}{c}\text { Coeficiente de Regressão } \\
R=0,536\end{array}$} \\
\hline \multicolumn{4}{|c|}{$\begin{array}{c}\text { Variância Explicada } \\
\mathrm{R}^{2}=0,288 \text { ou } 28,8 \% ; R^{2} \text { ajustado }=0,268 \text { ou } 26,8 \%\end{array}$} \\
\hline \multicolumn{4}{|c|}{$\begin{array}{c}\text { Teste Estatístico } \\
\mathrm{F}(2 / 76)=37,195 ; \mathrm{p}=0,000\end{array}$} \\
\hline
\end{tabular}

Fonte: Dados primários coletados pela autora. Adaptado de Demo (2008, p. 130)

Os resultados da análise de regressão apontaram como preditores da variável satisfação com a chefia, o comprometimento organizacional nas bases afetiva e calculativa. As suas contribuições para a explicação da variável dependente foram de $28,8 \%$, sendo $23,3 \%$ do comprometimento organizacional afetivo e $5,5 \%$ do comprometimento organizacional calculativo. Os comprometimentos organizacionais afetivo e calculativo se relacionam positivamente $(\beta>0)$ com a satisfação com a chefia, isso quer dizer que tanto o professor que esteja trabalhando porque gosta da instituição quanto também aquele que apenas trabalhará enquanto esta for a oportunidade mais atrativa para ele, mostram-se mais satisfeitos com a capacidade profissional da chefia, entendimento e relacionamento com o chefe. Destacou-se o comprometimento organizacional afetivo como o melhor preditor da satisfação com a chefia, de acordo com o modelo proposto.

\subsubsection{Regressão múltipla tendo como variável dependente a satisfação no trabalho com as promoções}

A Tabela 15 apresenta os principais resultados da regressão múltipla, tendo como variável dependente a satisfação com as promoções. 
Tabela 15: Preditores da satisfação com as promoções

\begin{tabular}{|c|c|c|c|}
\hline \multicolumn{4}{|c|}{ Variável dependente: Satisfação com as promoções } \\
\hline Variável & Beta $(\beta)$ & Sig. $(p<0,05)$ & $s r^{2}$ \\
\hline $\begin{array}{c}\text { Comprometimento } \\
\text { organizacional } \\
\text { afetivo }\end{array}$ & 0,328 & 0,00 & 0,162 \\
\hline $\begin{array}{l}\text { Comprometimento } \\
\text { organizacional } \\
\text { calculativo }\end{array}$ & 0,278 & 0,01 & 0,072 \\
\hline \multicolumn{4}{|c|}{$\begin{array}{c}\text { Coeficiente de Regressão } \\
R=0,484\end{array}$} \\
\hline \multicolumn{4}{|c|}{$\begin{array}{c}\text { Variância Explicada } \\
\mathrm{R}^{2}=0,234 \text { ou } 23,4 \% ; R^{2} \text { ajustado }=0,213 \text { ou } 21,3 \%\end{array}$} \\
\hline & $F(2 / 76)$ & $\begin{array}{l}\text { ístico } \\
; p<0,011\end{array}$ & \\
\hline
\end{tabular}

Fonte: Dados primários coletados pela autora. Adaptado de Demo (2008, p. 130)

Os resultados da análise de regressão apontaram como preditores da variável satisfação com as promoções, o comprometimento organizacional afetivo e calculativo. As suas contribuições para a explicação da variável dependente foi de $23,4 \%$, sendo $16,2 \%$ do comprometimento organizacional afetivo e $7,2 \%$ do comprometimento organizacional calculativo. Os comprometimentos organizacionais afetivo e calculativo se relacionam positivamente $(\beta>0)$ com a satisfação com as promoções, em outras palavras, tanto o professor que esteja trabalhando porque gosta da instituição quanto aquele que apenas trabalhará enquanto esta for a oportunidade mais atrativa para ele, tendem a se mostrar mais satisfeitos no que diz respeito às promoções em relação à quantidade, à maneira como é realizada e às oportunidades reconhecidas na UnB. Destacou-se 0 comprometimento organizacional afetivo como o melhor preditor da satisfação com as promoções, segundo o modelo proposto.

\subsubsection{Regressão múltipla tendo como variável dependente a satisfação no trabalho com a natureza do trabalho}

A Tabela 16 apresenta os principais resultados da regressão múltipla, tendo como variável dependente a satisfação com a natureza do trabalho. 
Tabela 16: Preditores da satisfação com a natureza do trabalho

\begin{tabular}{|c|c|c|c|}
\hline \multicolumn{4}{|c|}{ Variável dependente: Satisfação com a natureza do trabalho } \\
\hline Variável & Beta $(\beta)$ & Sig. $(p<0,05)$ & $\mathrm{sr}^{2}$ \\
\hline $\begin{array}{c}\text { Comprometimento } \\
\text { organizacional } \\
\text { afetivo }\end{array}$ & 0,387 & 0,00 & 0,149 \\
\hline \multicolumn{4}{|c|}{$\begin{array}{l}\text { Coeficiente de Regressão } \\
\qquad R=0,387\end{array}$} \\
\hline \multicolumn{4}{|c|}{$\begin{array}{c}\text { Variância Explicada } \\
R^{2}=0,149 \text { ou } 14,9 \% ; R^{2} \text { ajustado }=0,138 \text { ou } 13,8 \% \\
\end{array}$} \\
\hline \multicolumn{4}{|c|}{$\begin{array}{c}\text { Teste Estatístico } \\
\mathrm{F}(1 / 76)=12,996 ; \mathrm{p}<0,001\end{array}$} \\
\hline
\end{tabular}

Fonte: Dados primários coletados pela autora. Adaptado de Demo (2008, p. 130)

Os resultados da análise de regressão apontaram como preditor da variável satisfação com a natureza do trabalho, o comprometimento organizacional afetivo. A sua contribuição na explicação da variável dependente foi de 14, 9\%. O comprometimento organizacional afetivo se relaciona positivamente $(\beta>0)$ com a satisfação com os colegas. Isso que dizer que quanto mais o professor esteja trabalhando na UnB porque gosta dela, maior será sua satisfação com a natureza do trabalho e, maior o interesse pelas atividades, variedade e capacidade de absorção. O comprometimento organizacional afetivo foi o único preditor da satisfação com a natureza do trabalho, de acordo com o modelo proposto.

Para facilitar a melhor compreensão dos resultados engendrados, a Figura 2 apresenta os melhores preditores de cada fator das variáveis dependentes do modelo de pesquisa, conforme enunciado no objetivo geral do trabalho. 


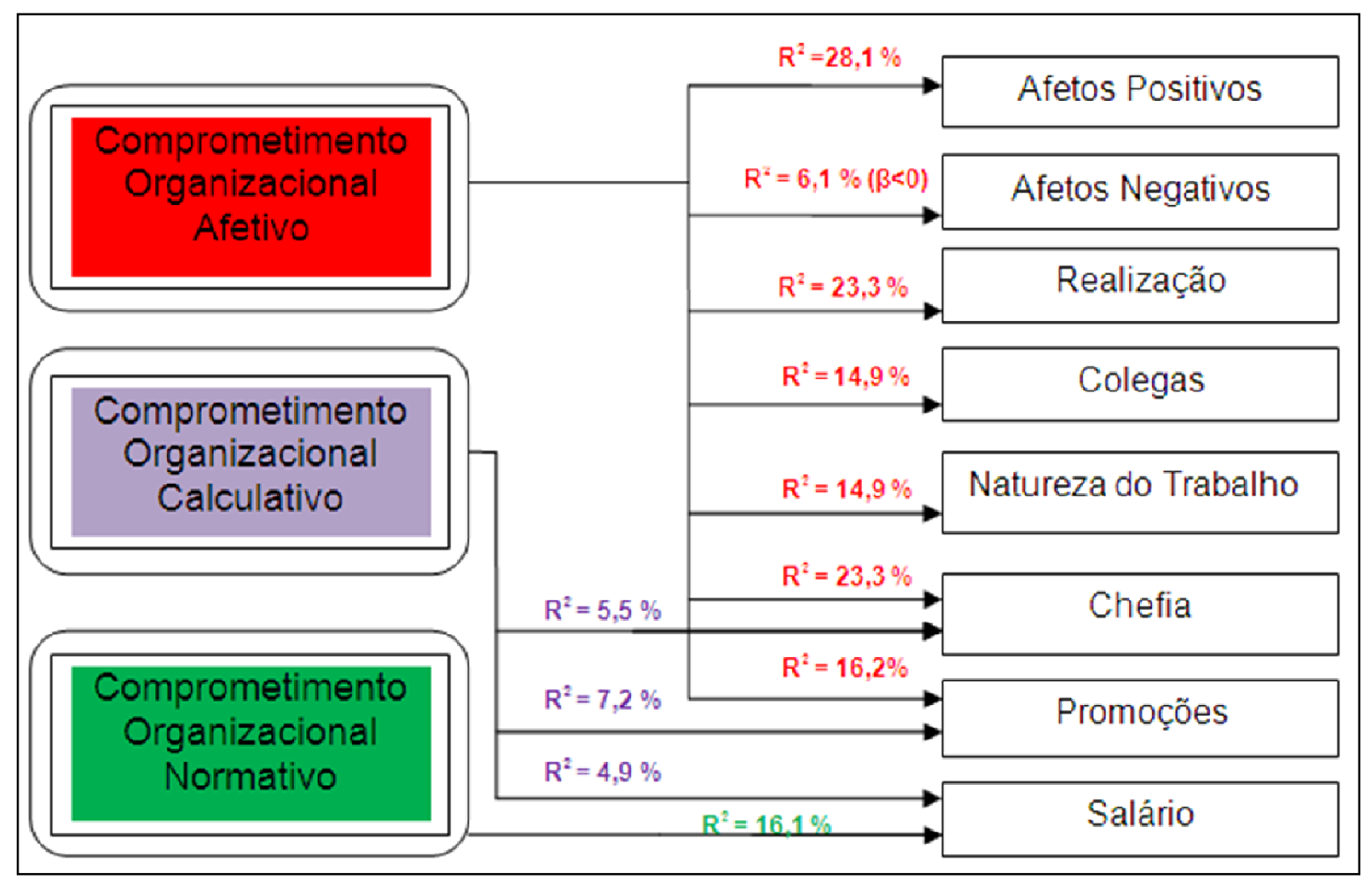

Figura 2: Os melhores preditores de cada fator das variáveis dependentes Fonte: Adaptado de Demo (2008, p. 136)

Em suma, respondendo à questão proposta na pesquisa, a saber, "professores que apresentam maior nível de comprometimento organizacional têm maior bem-estar no trabalho e são mais satisfeitos no trabalho?", a resposta é positiva, ou seja, o comprometimento organizacional, especialmente 0 comprometimento organizacional afetivo, contribui para a explicação do bem-estar e da satisfação no trabalho.

O próximo capítulo conclui o trabalho. 


\section{CONCLUSÕES E RECOMENDAÇÕES}

Nessa parte de conclusões e recomendações será apresentada a síntese dos principais resultados, as contribuições e limitações da pesquisa, bem como as recomendações para estudos futuros.

\subsection{Síntese dos resultados}

O objetivo principal da pesquisa realizada foi avaliar a influência do comprometimento organizacional dos professores que lecionam disciplinas de Administração na Universidade de Brasília em seu bem-estar e satisfação no trabalho, verificando os melhores preditores da satisfação no trabalho e do bemestar no trabalho a partir dos modelos propostos. No objetivo geral apresentado, estão os objetivos específicos, que buscaram identificar a percepção dos professores da UnB para cada variável, a saber, comprometimento organizacional, bem-estar e satisfação no trabalho.

Quanto à percepção dos professores, no que tange ao comprometimento organizacional, destacou-se a base afetiva. Em seguida, destacaram-se as dimensões "realização" e "afetos positivos" referentes ao bem-estar no trabalho e, por fim, os professores declararam-se satisfeitos no trabalho quanto à chefia, à natureza do trabalho e aos colegas.

Foram identificados os melhores preditores das variáveis "bem-estar no trabalho" e "satisfação no trabalho" e se destacou o comprometimento organizacional afetivo. O comprometimento organizacional afetivo foi preditor das dimensões "afetos positivos", "afetos negativos" e "realização" do bem-estar no trabalho, da "satisfação com os colegas" e da "satisfação com a natureza do trabalho". A "satisfação com o salário" foi explicada pelo comprometimento normativo e calculativo, enquanto que a "satisfação com a chefia" e a "satisfação com as promoções" foram explicadas pelo comprometimento organizacional afetivo e calculativo. 
Em tese, os gestores devem dar especial atenção ao compromisso afetivo de seus colaboradores, uma vez que este influencia todas as dimensões de bem-estar no trabalho, além de fatores da satisfação no trabalho, também influenciada pelas bases calculativa e normativa do comprometimento.

\subsection{Contribuições e limitações}

A pesquisa realizada contribuiu para o avanço de estudos relacionados ao comprometimento organizacional, bem-estar no trabalho e satisfação no trabalho, para melhor compreender e associar as variáveis de pesquisa, subsidiando os gestores em seu planejamento e tomada de decisões.

Dessa forma, a presente pesquisa foi realizada não apenas para desenvolver o assunto, mas, mais do que isso, contribuir para que os professores e alunos da Universidade de Brasília tenham um melhor ambiente de trabalho e ensino.

No que tange às limitações, trata-se inicialmente de um estudo de corte transversal, que impossibilita afirmações genéricas, cuja pesquisa é realizada em um único momento da realidade em uma instituição de ensino superior, vedando assim, qualquer tentativa de generalizar os resultados para organizações do setor público ou privado.

Outra limitação encontrada foi quanto ao tamanho da amostra, restringindo-se ao mínimo exigido para a validade do estudo. Devido ao pequeno universo, foi necessário e imprescindível contemplar professores com diferentes vínculos com a instituição, podendo para uma próxima investigação buscar maior precisão dos resultados a partir da separação em grupos como efetivados, substitutos e voluntários. A amostra também abrangeu professores recém contratados, o que pode ter causado vieses nos resultados.

Por fim, uma limitação quanto ao referencial teórico foi identificada. A variável comprometimento organizacional vem sendo estudada há mais tempo, fato que contribui para o maior número de estudos, ao passo que satisfação no trabalho e bem-estar no trabalho ainda têm exploração restrita, especialmente esta última, com poucos estudos publicados, afetando assim a produção do estado da arte sobre 
essas variáveis. Por outro lado, essa carência de publicações se traduz em um convite a mais pesquisas.

\subsection{Recomendações para estudos futuros}

O presente estudo foi realizado em um momento único da realidade, por isso, novos estudos são recomendados com vistas à continuidade do desenvolvimento de outras pesquisas. A partir disso, recomenda-se a realização de estudos longitudinais que reavaliem as variáveis pesquisadas após a adoção de medidas a partir dos resultados do presente estudo. Da mesma forma, expandir a pesquisa para outros cursos e se possível, para a UnB como um todo, no sentido de a Universidade planejar uma agenda com fins de melhoria nas atitudes e comportamentos de seus professores no trabalho.

Acrescentar outras variáveis que possam impactar a satisfação, o bem-estar e até mesmo o comprometimento como, por exemplo, as políticas de gestão de pessoas, pode melhorar a qualidade do modelo. Ademais, ressalta-se que estudos qualitativos devem ser mais explorados no afã de obter melhor compreensão dos construtos em estudo.

Primordial se faz a realização de pesquisas sobre bem-estar no trabalho. A produção nacional carece de trabalhos sobre esse assunto na área de Administração. Para a produção nacional dessa variável, não se encontraram estudos nos periódicos de Administração, só nos de Psicologia. A tendência é que estudos futuros versem sobre a variável bem-estar no trabalho e sobre as possíveis relações com outras variáveis do comportamento organizacional.

A partir do referencial teórico, constatou-se que grande parte dos estudos são quantitativos e realizados em organizações públicas. Destarte, estudos qualitativos e quali-quanti, como já colocado, são bem-vindos e as realidades de organizações privadas e não governamentais (terceiro setor) também devem ser perscrutadas com o objetivo de incrementar a generalidade dos resultados obtidos.

Por fim, as recomendações não são conclusivas, apenas ressaltam a necessidade de atualização e a realização constante de pesquisas para melhor 
entender a área estudada, contribuindo para que o ambiente de trabalho seja acolhedor e onde o colaborador possa desenvolver melhor suas capacidades. 


\section{REFERÊNCIAS}

ALBUQUERQUE, A. S.; TRÓCCOLI, B. T. Desenvolvimento de uma escala de bemestar subjetivo. Psicologia: Teoria e Pesquisa, Brasília, v. 20, n. 2, 2004.

ALLEN, N. J.; MEYER, J. P. The measurement and antecedents of affective, continuance and normative commitment to the organization. Journal of Occupational Psychology, Leicester, v. 63, n. 2, 1990.

BASTOS, A. V. B. Comprometimento organizacional: um balanço dos resultados e desafios que cercam essa tradição de pesquisa. Revista de Administração de Empresas, São Paulo, v. 33, n. 3, 1993.

BERNSTORFF, V. H. A intensificação do trabalho, a satisfação profissional e seus efeitos sobre o estresse ocupacional. In: XXXI Encontro da ANPAD (EnANPAD), 2007, Rio de Janeiro. Anais...Rio de Janeiro: XXXI EnANPAD, $2007 a$.

. A satisfação profissional e as influências da organização do trabalho. In: XXXI Encontro da ANPAD (EnANPAD), 2007, Rio de Janeiro. Anais...Rio de Janeiro: XXXI EnANPAD, 2007b.

. DAL ROSSO, S. O absenteísmo ao trabalho como forma de resistência individual à intensificação do trabalho, à insatisfação profissional e ao estresse ocupacional. In: XXXII Encontro da ANPAD (EnANPAD), 2008, Rio de Janeiro. Anais...Rio de Janeiro: XXXI EnANPAD, 2008.

BUTLER, M. C.; EHRICH, E. J. Positional influences on job satisfaction and job performance: A multivariate predictive approach. Psychological Reports, Missoula, v. 69 , n. $1,1999$.

CAMPBELL, K. N. Adult education: Helping adults Begin the process of learning. Journal of the American Association of Occupational Health Nurses, Pensacola, v. 47 , n. 1, 1999.

CAMPOS, C. V. A.; MALIK, A. M. Satisfação no trabalho e rotatividade dos médicos do Programa de Saúde da Família. Revista de Administração Pública, Rio de Janeiro, v. 42, n. 2, 2008.

CARNEIRO, T. L.; CARVALHO, J. L. Trabalho em transição, saúde em risco.

Psicologia: Teoria e Pesquisa, Brasília, v. 19, n. 2, 2003. 
COELHO JUNIOR, F. A.; MOURA, C. F. Re-validação de escala de satisfação no trabalho. In: XXXII Encontro da ANPAD (EnANPAD), 2008, Rio de Janeiro.

Anais...Rio de Janeiro: XXXII EnANPAD, 2008.

COHEN, J. A power primer. Psychological Bulletin, New York, v. 112, n. 1, 1992.

COLLIS, J.; HUSSEY, R. Pesquisa em administração: um guia prático para alunos de graduação e pós-graduação. 2. ed. Porto Alegre: Bookman, 2005.

CUNICO, L. H.; ZAMPIER, M. A. Predição de satisfação de funcionários de uma rede de lojas do comércio varejista através da aplicação de técnicas em Data Mining. In: XXXII Encontro da ANPAD (EnANPAD), 2008, Rio de Janeiro.

Anais...Rio de Janeiro: XXXII EnANPAD, 2008.

DANIELS, K. Measures of Five aspects of affective well-being at work. Human Relations, London, v. 53, n. 2, 2000.

DEMO, G. Comprometimento no trabalho: uma síntese do estado da arte e uma revisão da produção nacional. Revista Psicologia: Organizações e Trabalho, Florianópolis, v. 3, n. 2, 2003.

Políticas de gestão de pessoas nas organizações: papel dos valores pessoais e da justiça organizacional. 2. ed. São Paulo: Atlas, 2008.

. PONTE, V. Marketing de relacionamento (CRM): estado da arte e estudo de casos. São Paulo: Atlas, 2008.

DEMO, P. Metodologia científica em ciências sociais. 2. ed. São Paulo: Atlas, 1989.

DIENER, E. Subjective well-being: The science of happiness and a proposal for a national index. American Psychologist, Washington, v. 55, n. 1, 2000.

EVANS, O.; STEPTOE, A. The contribution of gender-role orientation, work factors and home stressors to psychological well-being and sickness absence in male and female-dominated occupational groups. Social Science and Medicine, Maryland Heights, v. 54, n. 4, 2002.

GIL, A. C. Métodos e técnicas de pesquisa social. São Paulo: Atlas, 1999.

GOMIDE JÚNIOR, S.; HERNANDEZ, J. D. Bem-estar no trabalho: os estudos realizados na Universidade Federal de Uberlândia. Revista da Sociedade de Psicologia do Triângulo Mineiro, Uberlândia, v. 9, n. 1, 2005. 
GOUVEIA, V. V. et al. Escala de bem-estar afetivo no trabalho (Jaws): evidências de validade fatorial e consistência interna. Psicologia: Reflexão e Crítica, Porto Alegre, v. 21, n. 3, 2008. Disponível em:

$<$ http://www.scielo.br/scielo.php?script=sci_arttext\&pid=S0102-

$79722008000300015 \&$ lng=en\&nrm=iso>. Acesso em: 27 set. 2009.

HAZAN, C.; SHAVER, P. R. Love and work: an attachment theoretical perspective. Journal of Personality and Social Psychology, Washington, v. 59, n. 1, 1990.

HELLMAN, C. M. Job satisfaction and the intent to leave. Journal of Personality and Social Psychology, Washington, v. 137, n. 6, 1997.

JACKSON, C. J.; CORR, P. J. Global job satisfaction and facet description: The moderating role of facet importance. European Journal of Psychological

Assessment, Cambridge, v. 18, n. 1, 2002.

KABANOFF, B. Work and nonwork: a review of models, methods and findings.

Psychological Bulletin, Washington, v. 88, n. 1, 1980.

KATZ, D.; KAHN, R. L. Psicologia social das organizações. São Paulo: Atlas, 1978.

KERLINGER, F. N. Metodologia da pesquisa em ciências sociais: um tratamento conceitual. São Paulo: EPU, 1980.

KIRSCHENBAUM, A. et al. Well being, work environment and work accidents. Social Science and Medicine, Maryland Heights, v. 50, n. 5, 2000.

KRAUSZ, M.; KOLOWSKY, M.; EISER, A. Distal and proximal influences on turnover intention and satisfaction: Support for a withdrawal progression theory. Journal of Vocational Behavior, Maryland Heights, v. 52, n. 1, 1998.

MÄKIKANGAS, A.; KINNUNEM, U. Psychosocial work stressors and well-being: Selfesteem and optimism as moderators in a one-year longitudinal sample. Personality and Individual Differences, Maryland Heights, v. 35, n. 3, 2003.

MARCONI, M. A.; LAKATOS, E. M. Metodologia Científica. 4. ed. São Paulo: Atlas, 2004.

Técnicas de pesquisa. 7. ed. São Paulo: Atlas, 2008. 
MARINHO, M. S. C. Satisfação no trabalho: uma revisão conceitual para a análise empírica. Ciência e Cultura, São Paulo, v. 40, n. 3, 1988.

MARTINEZ, M. C. As relações entre a satisfação com aspectos psicossociais no trabalho e a saúde do trabalhador. 2002. 255 f. Dissertação (Mestrado em Saúde Ambiental) - Faculdade de Saúde Pública da Universidade de São Paulo, São Paulo, 2002.

MARTINS, M. C. F.; SANTOS, G. E. Adaptação e validação de construto da escala de satisfação no trabalho. Psico - USF, Bragança Paulista, v. 11, n. 2, 2006. Disponível em: <http://pepsic.bvs-psi.org.br/pdf/psicousf/v11n2/v11n2a08.pdf>. Acesso: 13 set. 2009.

MARTINS, P. R. Gestão de pessoas na Livraria Cultura: o papel das políticas e práticas de gestão de pessoas no comprometimento organizacional e na satisfação no trabalho. 2009. 120 f. Monografia (Especialização - MBA de gestão de serviços e atendimento ao cliente) - FGV Management, Brasília, 2009.

MEDEIROS, C. A. F. et al. Três (ou quatro?) componentes do comprometimento organizacional. In: XXIII Encontro da ANPAD (EnANPAD), 1999, Rio de Janeiro. Anais...Rio de Janeiro: XXIII EnANPAD, 1999.

. et al. Comprometimento organizacional: o estado da arte da pesquisa no Brasil. Revista de Administração Contemporânea, São Paulo, v. 7, n. 4, 2003.

MINAYO, M. C. S. O desafio do conhecimento. São Paulo: Hucitec, 1993.

MORIN, E. M. Os sentidos do trabalho. Revista de Administração de Empresas, São Paulo, v. 41, n. 3, 2001.

O'REILLY, C. A.; PFEFFER, J. Talentos ocultos: como as melhores empresas obtem resultados extraordinários com pessoas comuns. Rio de Janeiro: Campus, 2001.

PAIVA, C. S. D. L; BORGES, L. O. O ambiente de trabalho no setor bancário e o bem-estar. Psicologia em Estudo, Maringá, v. 14, n. 1, 2009.

PASCHOAL, T.; TAMAYO, A. Construção e validação da escala de bem-estar no trabalho. Avaliação Psicológica, Porto Alegre, v. 7, n. 1, 2008. Disponível em: $<$ http://pepsic.bvs-psi.org.br/scielo.php?script=sci_arttext\&pid=S167704712008000100004\&lng=pt\&nrm=iso >. Acesso em: 13 set. 2009. 
PASQUALI, L. Análise fatorial para pesquisadores. Laboratório de Pesquisa em Avaliação e Medida (LabPAM) - Instituto de Psicologia. Brasília: Universidade de Brasília, 2001.

PAZ, M. G. T. Poder e saúde organizacional. In: TAMAYO, A. (Org.). Cultura e saúde nas organizações. Porto Alegre: Artmed Bookman, 2004.

PIMENTA, S. G; ANASTASIOU, L. G. C. Docência no ensino superior. São Paulo: Cortez, 2002.

PORTO, J. B.; TAMAYO, A. Escala de valores relativos ao trabalho: EVT.

Psicologia: Teoria e Pesquisa, Brasília, v. 19, n. 2, 2003.

PUENTES-PALACIOS, K. E.; BORGES-ANDRADE, J. E. O efeito da interdependência na satisfação de equipes de trabalho: um estudo multinível. Revista de Administração Contemporânea, Curitiba, v. 9, n. 3, 2005. Disponível em: < http://www.scielo.br/scielo.php?script=sci_arttext\&pid=S1415$65552005000300004 \&$ Ing=en\&nrm=iso >. Acesso em: 13 set. 2009.

RIFF, C. D. Happiness is everything, or is it? Explorations on the meaning of Psychological well-being. Journal of Personality and Social Psychology, Washington, v. 57, n. 6, 1989.

RYAN, R. M.; DECI, E. L. On happiness and human potentials: A review of research on hedonic and eudaimonic well-being. Annual Review of Psychology, California, v. 52, n. 1, 2001.

SANT'ANNA, A. S.; MORAES, L. F. R.; KILIMNIK, Z. M. Competências individuais, modernidade organizacional e satisfação no trabalho: um estudo de diagnóstico comparativo. RAE - eletrônica, São Paulo, v. 4, n. 1, 2005. Disponível em: < http://www.rae.com.br/eletronica/index.cfm?FuseAction=Artigo\&ID=1696\&Secao=AR TIGOS\&Volume=4\&Numero=1\&Ano=2005>. Acesso em: 13 set. 2009.

SIQUEIRA, M. M. M. Antecedentes de comportamentos de cidadania organizacional: a análise de um modelo pós-cognitivo. 1995. 265 f. Tese (Doutorado em Psicologia) - Instituto de Psicologia da Universidade de Brasília, Brasília, 1995.

Análises de três medidas de comprometimento organizacional: afetivo, calculativo e normativo. VIII Conferência Internacional de avaliação psicológica. Anais... Belo Horizonte, 2000. 
(Org.). Psicologia, organizações e trabalho no Brasil. Porto Alegre: Artmed Bookman, 2004.

.PADOVAM, V. A. R. Bases teóricas de bem-estar subjetivo, bem-estar psicológico e bem-estar no trabalho. Psicologia: Teoria e Pesquisa, Brasília, v. 24, n. 2, 2008.

STAW, B. M.; ROSS, J. Stability in the midst of change: A dispositional approach to job attitudes. Journal of Applied Psychology, Washington, v. 70, n. 1, 1985.

TAMAYO, A. Valores organizacionais: sua relação com satisfação no trabalho, cidadania organizacional e comprometimento afetivo. Revista de Administração, São Paulo, v. 33, n. 3, 1998.

(Org.). Cultura e saúde nas organizações. Porto Alegre: Artmed Bookman, 2004.

UNIVERSIDADE DE BRASÍLIA. Sobre a UnB. Disponível em: <www.unb.br/sobre>. Acesso em 13 set. 2009.

VALLE, A. R. Monitoramento da satisfação no trabalho em uma empresa finaceira. 2007. $180 \mathrm{f}$. Tese (Doutorado em Psicologia) - Instituto de Psicologia da Universidade de Brasília, Brasília, 2007.

VAN HORN, J. E. et al. The structure of occupational well-being: a study among dutch teachers. Journal of Occupational and Organizational Psychology, Leicester, v. 77, n. 3, 2004.

VERGARA, C. S. Métodos de pesquisa em administração. São Paulo: Atlas, 2006.

WATERMAN, A. S. Two conceptions of happiness: contrasts of personal expressiveness (eudaimonia) and hedonic enjoyment. Journal of Personality and Social Psychology, Washington, v. 64, n. 4, 1993.

WEISS, H. M. Desconstructing job satisfaction: Separations, beliefs and affective experiences. Human Resource Management Review, Maryland Heights, v. 12, n. 2, 2002.

WETZEL, U. Transformação do contrato psicológico no contexto da privatização: estudo de casos. Revista de Administração Contemporânea, Curitiba, v. 5, n. spe, 
2001. Disponível em: <http://www.scielo.br/scielo.php?script=sci_arttext\&pid=S1415$65552001000500012 \&$ Ing=en\&nrm=iso>. Acesso em: 27 out. 2009. 


\section{ANEXOS \\ Anexo A - Questionário}

Caro (a) Professor (a),

Eu, Maria Teodora Farias Traldi, formanda em Administração de Empresas UnB, estou elaborando a monografia de final de curso com o tema "bem estar, comprometimento e satisfação dos professores de administração da UnB".

Gostaria de contar com sua colaboração no sentido de responder ao questionário a seguir que está dividido em três partes com as devidas orientações para preenchimento. O questionário é todo objetivo e bem simples de responder.

Preciso de sua sinceridade nas respostas. Lembre-se de que não há respostas certas ou erradas. Todas são corretas desde que correspondam ao que você pensa.

É importante lembrar que você não deve se identificar (não são solicitadas informações neste sentido em nenhum momento) e que os resultados desta pesquisa serão utilizados exclusivamente para fins acadêmicos.

\section{Por gentileza, não deixe nenhum item em branco!}

Quaisquer dúvidas ou esclarecimentos sobre o preenchimento do questionário, estarei à sua disposição ou você pode entrar em contato diretamente comigo pelo e-mail teodoratraldi@hotmail.com.

A SUA COLABORAÇÃO É MUITO IMPORTANTE !

OBRIGADA !

Maria Teodora Farias Traldi 


\section{Escala de Bem-Estar no Trabalho}

Para responder a esta parte do questionário, utilize a escala abaixo e escreva $o$ número que melhor expressa sua resposta ao lado de cada item.

\begin{tabular}{|ccccc|}
\hline Nem um pouco & Um pouco & Moderadamente & Bastante & Extremamente \\
1 & 2 & 3 & 4 & 5 \\
\hline
\end{tabular}

Nos últimos seis meses, meu trabalho tem me deixado...
1) alegre
8) animado
15) incomodado
2) preocupado
9) chateado
16)nervoso
3) disposto
10)impaciente
17)empolgado
4) contente
11)entusiasmado
18)tenso
5) irritado
12)ansioso
19)orgulhoso
6) deprimido
13) feliz
7) entediado
14)frustrado
20)com raiva
21)tranquilo

Agora você deve indicar o quanto as afirmações abaixo representam suas opiniões sobre o seu trabalho.

Para responder aos itens, utilize a escala seguinte e assinale o número que melhor corresponde à sua resposta.

\begin{tabular}{|ccccc|}
\hline Discordo & Discordo & Concordo & Concordo & Concordo \\
Totalmente & 2 & em parte & & Totalmente \\
1 & 2 & 3 & 4 & 5 \\
\hline
\end{tabular}

Neste trabalho...

\begin{tabular}{|llllll|}
\hline 22) Realizo o meu potencial & 1 & 2 & 3 & 4 & 5 \\
\hline 23) Desenvolvo habilidades que considero importantes & 1 & 2 & 3 & 4 & 5 \\
\hline $\begin{array}{l}\text { 24)Realizo atividades que expressam minhas } \\
\text { capacidades }\end{array}$ & 1 & 2 & 3 & 4 & 5 \\
\hline 25) Consigo recompensas importantes para mim & 1 & 2 & 3 & 4 & 5 \\
\hline 26) Supero desafios & 1 & 2 & 3 & 4 & 5 \\
\hline 27) Atinjo resultados que valorizo & 1 & 2 & 3 & 4 & 5 \\
\hline 28) Avanço nas metas que estabeleci para minha vida & 1 & 2 & 3 & 4 & 5 \\
\hline 29) Faço o que realmente gosto de fazer & 1 & 2 & 3 & 4 & 5 \\
\hline 30) Expresso o que há de melhor em mim & 1 & 2 & 3 & 4 & 5 \\
\hline
\end{tabular}

\section{Escala de Comprometimento no Trabalho}

PARTE I (ESCALA DE COMPROMETIMENTO AFETIVO)

Você encontrará a seguir alguns sentimentos/emoções que alguém poderia ter em relação à instituição onde trabalha. Queremos saber O QUANTO VOCÊ SENTE ESTES SENTIMENTOS E EMOÇÕES em relação à UnB. 
Para responder, assinale com "X" apenas um dos códigos da escala de 1 a 5 , à direita de cada item, que significam:

\begin{tabular}{|ccccc|}
\hline Nada & Pouco & $\begin{array}{c}\text { Mais ou } \\
\text { menos }\end{array}$ & Muito & Extremamente \\
1 & 2 & 3 & 4 & 5 \\
\hline
\end{tabular}

A UnB FAZ-ME SENTIR...

\begin{tabular}{|l|l|c|c|c|c|c|}
\hline$N^{\circ}$ & ITENS & Nada & $\begin{array}{c}2 \\
\text { Pouco }\end{array}$ & $\begin{array}{c}3 \\
\text { Mais ou } \\
\text { menos }\end{array}$ & $\begin{array}{c}4 \\
\text { Muito }\end{array}$ & Extremamente \\
\hline 31 & Orgulhoso dela & & & & & \\
\hline 32 & Contente com ela & & & & & \\
\hline 33 & Entusiasmado com ela & & & & & \\
\hline 34 & Interessado por ela & & & & & \\
\hline 35 & Animado com ela & & & & & \\
\hline
\end{tabular}

PARTE II (ESCALA DE COMPROMETIMENTO CALCULATIVO)

Agora serão apresentadas algumas frases que falam perdas e dificuldades que você teria se pedisse demissão da UnB e fosse trabalhar para outra instituição. Queremos saber O QUANTO VOCÊ CONCORDA OU DISCORDA DE CADA FRASE.

Para responder, assinale com "X" apenas um dos códigos da escala de 1 a 5 , à direita de cada frase, que significam:

\begin{tabular}{|ccccc|}
\hline $\begin{array}{c}\text { Discordo } \\
\text { Totalmente }\end{array}$ & Discordo & $\begin{array}{c}\text { Nem concordo } \\
\text { nem discordo }\end{array}$ & Concordo & $\begin{array}{c}\text { Concordo } \\
\text { Totalmente }\end{array}$ \\
1 & 2 & 3 & 4 & 5 \\
\hline
\end{tabular}

PEDIR DEMISSÃO DA UnB E IR TRABALHAR EM OUTRA INSTITUIÇÃO NÃO VALERIA A PENA PORQUE...

\begin{tabular}{|l|l|c|c|c|c|c|}
\hline$N^{\circ}$ & \multicolumn{1}{|c|}{ ITENS } & $\begin{array}{c}\mathbf{1} \\
\text { Discordo } \\
\text { totalmente }\end{array}$ & $\begin{array}{c}\mathbf{2} \\
\text { Discordo }\end{array}$ & $\begin{array}{c}\mathbf{3} \\
\text { Nem concordo } \\
\text { nem discordo }\end{array}$ & $\begin{array}{c}\mathbf{4} \\
\text { Concordo }\end{array}$ & $\begin{array}{c}\mathbf{5} \\
\text { Concordo } \\
\text { Totalmente }\end{array}$ \\
\hline 36 & $\begin{array}{l}\text { Eu teria dificuldade para ganhar um } \\
\text { salário tão bom quanto o que eu tenho } \\
\text { hoje }\end{array}$ & & & & \\
\hline 37 & $\begin{array}{l}\text { Eu jogaria fora todos os esforços que fiz } \\
\text { para chegar onde cheguei dentro desta } \\
\text { instituição }\end{array}$ & $\begin{array}{l}\text { Eu perderia a estabilidade no emprego } \\
\text { que tenho hoje nesta instituição }\end{array}$ & & & & \\
\hline 39 & $\begin{array}{l}\text { Eu teria dificuldade para conseguir outro } \\
\text { cargo que me desse o mesmo prestigio } \\
\text { que tenho com o meu cargo atual }\end{array}$ & & & & & \\
\hline
\end{tabular}




\begin{tabular}{|c|c|c|c|c|c|c|}
\hline $\mathrm{N}^{0}$ & ITENS & $\begin{array}{c}1 \\
\text { Discordo } \\
\text { totalmente }\end{array}$ & $\begin{array}{l}2 \\
\text { Discordo }\end{array}$ & $\begin{array}{c}3 \\
\begin{array}{c}\text { Nem concordo } \\
\text { nem discordo }\end{array} \\
\end{array}$ & $\begin{array}{l}4 \\
\text { Concordo }\end{array}$ & $\begin{array}{c}\mathbf{5} \\
\text { Concordo } \\
\text { Totalmente }\end{array}$ \\
\hline 40 & $\begin{array}{l}\text { Eu demoraria para encontrar em outra } \\
\text { instituição pessoas tão amigas quanto as } \\
\text { que eu tenho hoje entre meus colegas } \\
\text { de trabalho dentro desta instituicão }\end{array}$ & & & & & \\
\hline 41 & $\begin{array}{l}\text { Eu perderia a liberdade que tenho de } \\
\text { realizar meu trabalho dentro desta } \\
\text { instituição }\end{array}$ & & & & & \\
\hline 42 & $\begin{array}{l}\text { Eu estaria desperdiçando todo o tempo } \\
\text { que já me dediquei a esta instituição }\end{array}$ & & & & & \\
\hline 43 & $\begin{array}{l}\text { Eu deixaria para trás tudo o que já } \\
\text { investi nesta instituição }\end{array}$ & & & & & \\
\hline 44 & $\begin{array}{l}\text { Eu estaria prejudicando minha vida } \\
\text { profissional }\end{array}$ & & & & & \\
\hline 45 & $\begin{array}{l}\text { Eu demoraria para conseguir ser tão } \\
\text { respeitado em outra instituição como sou } \\
\text { hoje dentro desta instituição }\end{array}$ & & & & & \\
\hline 46 & $\begin{array}{l}\text { Eu deixaria de receber vários benefícios } \\
\text { que esta instituição oferece a seus } \\
\text { professores }\end{array}$ & & & & & \\
\hline 47 & $\begin{array}{l}\text { Eu teria mais coisas a perder do que a } \\
\text { ganhar com este pedido de demissão }\end{array}$ & & & & & \\
\hline 48 & $\begin{array}{l}\text { Eu perderia o prestigio que tenho hoje } \\
\text { por ser professor desta instituição }\end{array}$ & & & & & \\
\hline 49 & $\begin{array}{l}\text { Eu levaria muito tempo para me } \\
\text { acostumar com um novo trabalho }\end{array}$ & & & & & \\
\hline 50 & $\begin{array}{l}\text { Eu estaria jogando fora todo o esforço } \\
\text { que fiz para aprender as tarefas do meu } \\
\text { carao atual. }\end{array}$ & & & & & \\
\hline
\end{tabular}

\section{PARTE III (ESCALA DE COMPROMETIMENTO NORMATIVO).}

A seguir são apresentadas 7 frases relativas ao seu vínculo com a instituição. INDIQUE O QUANTO VOCÊ CONCORDA OU DISCORDA DE CADA UMA DELAS.

Para responder, assinale com "X" apenas um dos códigos da escala de 1 a 5 , à direita de cada frase, que significam:

\begin{tabular}{|ccccc|}
\hline Discordo & Discordo & $\begin{array}{c}\text { Nem concordo } \\
\text { nem discordo }\end{array}$ & Concordo & Concordo \\
Totalmente & 2 & 3 & 4 & Totalmente \\
1 & 2 & & & 5 \\
\hline
\end{tabular}

\begin{tabular}{|l|l|c|c|c|c|c|}
\hline$N^{\circ}$ & ITENS & $\begin{array}{c}\mathbf{1} \\
\text { Discordo } \\
\text { totalmente }\end{array}$ & $\begin{array}{c}\mathbf{2} \\
\text { Discordo }\end{array}$ & $\begin{array}{c}\mathbf{3} \\
\text { Nem concoroo } \\
\text { nem discordo }\end{array}$ & $\begin{array}{c}\mathbf{4} \\
\text { Concordo }\end{array}$ & $\begin{array}{c}\mathbf{5} \\
\text { Concordo } \\
\text { Totalamente }\end{array}$ \\
\hline 51 & $\begin{array}{l}\text { Continuar trabalhando nessa } \\
\text { instituição é uma forma de retribuir o } \\
\text { que ela já fez por mim }\end{array}$ & & & & \\
\hline
\end{tabular}




\begin{tabular}{|l|l|l|l|l|l|l|}
\hline$N^{\circ}$ & \multicolumn{1}{|c|}{ ITENS } & $\begin{array}{c}\mathbf{1} \\
\text { Discordo } \\
\text { totalmente }\end{array}$ & $\begin{array}{c}\mathbf{2} \\
\text { Discordo }\end{array}$ & $\begin{array}{c}\text { 3 } \\
\text { Nem concordo } \\
\text { nem discordo }\end{array}$ & $\begin{array}{c}\mathbf{4} \\
\text { Concordo }\end{array}$ & $\begin{array}{c}\mathbf{5} \\
\text { Concordo } \\
\text { Totalmente }\end{array}$ \\
\hline 52 & $\begin{array}{l}\text { Trabalharei nessa instituição } \\
\text { enquanto achar que devo algo a ela }\end{array}$ & & & & & \\
\hline 53 & $\begin{array}{l}\text { Eu seria injusto com essa instituição } \\
\text { se pedisse demissão agora e fosse } \\
\text { trabalhar para outra. }\end{array}$ & & & & & \\
\hline 54 & $\begin{array}{l}\text { Nesse momento essa instituição } \\
\text { precisa dos meus serviços }\end{array}$ & & & & & \\
\hline 55 & $\begin{array}{l}\text { Seria desonesto de minha parte ir } \\
\text { trabalhar para outra instituição agora } \\
\text { É a gratidão por essa instituição que } \\
\text { me mantém ligado a ela }\end{array}$ & & & & & \\
\hline 57 & $\begin{array}{l}\text { Essa instituição já fez muito por mim } \\
\text { no passado }\end{array}$ & & & & & \\
\hline
\end{tabular}

\section{Escala de Satisfação no Trabalho}

As próximas frases apresentadas falam a respeito de alguns aspectos do seu trabalho atual. Queremos saber: O QUANTO VOCÊ SE SENTE SATISFEITO OU INSATISFEITO COM CADA UM DELES.

Para responder, assinale com "X" apenas um dos códigos da escala de 1 a 5 , à direita de cada frase, que significam:

\begin{tabular}{|ccccc|}
\hline Muito Insatisfeito & Insatisfeito & Indiferente & Satisfeito & Muito \\
1 & 2 & 3 & 4 & Satisfeito \\
\hline
\end{tabular}

\section{AFIRMATIVAS}

\begin{tabular}{|c|c|c|c|c|c|c|}
\hline $\mathrm{N}^{\circ}$ & ITENS & $\begin{array}{c}1 \\
\text { Muito } \\
\text { Insatisfeito }\end{array}$ & $\underset{2}{2}$ & $\begin{array}{l}3 \\
\text { Indiferente }\end{array}$ & $\begin{array}{c}4 \\
\\
\text { Satisfeito }\end{array}$ & $\begin{array}{c}\mathbf{5} \\
\text { Muito } \\
\text { satisfeito }\end{array}$ \\
\hline 58 & $\begin{array}{l}\text { Com o espírito de colaboração dos } \\
\text { meus colegas de trabalho. }\end{array}$ & & & & & \\
\hline 59 & $\begin{array}{l}\text { Com o número de vezes que já fui } \\
\text { promovido nesta instituição. }\end{array}$ & & & & & \\
\hline 60 & $\begin{array}{l}\text { Com o meu salário comparado com o } \\
\text { quanto eu trabalho. }\end{array}$ & & & & & \\
\hline 61 & $\begin{array}{l}\text { Com o tipo de amizade que meus } \\
\text { colegas demonstram por mim. }\end{array}$ & & & & & \\
\hline 62 & $\begin{array}{l}\text { Com o grau de interesse que minhas } \\
\text { tarefas me despertam. }\end{array}$ & & & & & \\
\hline 63 & $\begin{array}{l}\text { Com o meu salário comparado à } \\
\text { minha capacidade profissional. }\end{array}$ & & & & & \\
\hline 64 & $\begin{array}{l}\text { Com a maneira que esta instituição } \\
\text { realiza promoções de seu pessoal. }\end{array}$ & & & & & \\
\hline 65 & $\begin{array}{l}\text { Com a capacidade de o meu trabalho } \\
\text { me absorver. }\end{array}$ & & & & & \\
\hline 66 & $\begin{array}{l}\text { Com as oportunidades de ser } \\
\text { promovido nesta instituição. }\end{array}$ & & & & & \\
\hline 67 & $\begin{array}{l}\text { Com o entendimento entre mim e } \\
\text { meu chefe. }\end{array}$ & & & & & \\
\hline
\end{tabular}




\begin{tabular}{|l|l|l|l|l|l|l|}
\hline$N^{\circ}$ & \multicolumn{1}{|c|}{ ITENS } & $\begin{array}{c}\mathbf{1} \\
\text { Muito } \\
\text { Insatisfeito }\end{array}$ & $\begin{array}{c}\mathbf{2} \\
\text { Insatisfeito }\end{array}$ & $\begin{array}{c}\mathbf{3} \\
\text { Indiferente }\end{array}$ & $\begin{array}{c}\mathbf{4} \\
\text { Satisfeito }\end{array}$ & $\begin{array}{c}\mathbf{5} \\
\text { Muito } \\
\text { satisfeito }\end{array}$ \\
\hline 68 & $\begin{array}{l}\text { Com o meu salário comparado com } \\
\text { meus esforços no trabalho. }\end{array}$ & & & & \\
\hline 69 & $\begin{array}{l}\text { Com a maneira como meu chefe me } \\
\text { trata. }\end{array}$ & & & & \\
\hline 70 & $\begin{array}{l}\text { Com a variedade de tarefas que } \\
\text { realizo. }\end{array}$ & $\begin{array}{l}\text { Com a confiança que eu posso ter } \\
\text { em meus colegas de trabalho. }\end{array}$ & & & & \\
\hline 72 & $\begin{array}{l}\text { Com a capacidade profissional do } \\
\text { meu chefe. }\end{array}$ & & & & \\
\hline
\end{tabular}

